Latvijas Universitātes

Pedagoǵijas, psiholoğijas un mākslas fakultātes Pedagoğijas zinātniskais institūts

\title{
Skolēnu morālā audzināšana Latvijas skolās: vecāku, skolotāju, topošo skolotāju un skolu un izglītības pārvaldes vadītāju viedokḷli Populārzinātniskais pētījuma ziṇojums
}

\author{
Dr. Manuel Joaquín Fernández González \\ Latvijas Universitātes \\ Pedagogijas, psihologijas un mākslas fakultātes \\ Pedagogijas zinātniskā institūta \\ vadošais pētnieks, pēcdoktorants, \\ Latvijas Zinātnes padomes eksperts \\ manuels.fernandezs@1u.lv
}

Pēcdoktorantūras projekts

"Izglītības modernizācija Latvijas skolās, īstenojot inovatīvu pētniecībā balstītu programmu par 21. gadsimta kompetencēm un tikumu ētikas attīstību ar virtuālās telpas atbalstu (ARETE-school)"

projekta Nr. 1.1.1.2/VIAA/1/16/071 


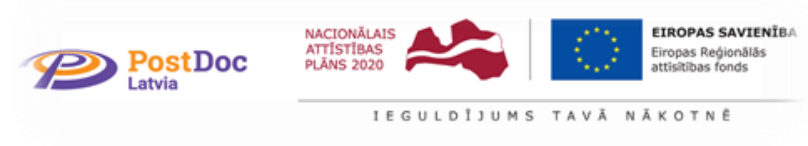

\section{Ievads pētījuma ziņojumam}

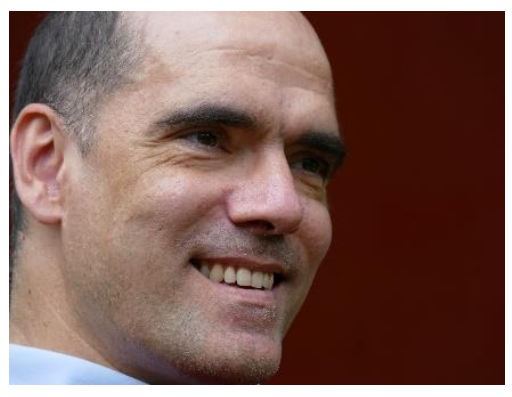

2018. gadā tika veikts ievērojams pētījums par skolēnu morālo ieradumu veidošanos Latvijas skolās, kurā piedalījās vairāk nekā 2250 respondentu (skolēni, skolotāji, vecāki, topošie skolotāji un skolu vadītāji) no visiem Latvijas reǵioniem. Respondenti aizpildīja starptautiski validētu anketu, kā arī dalījās ar savu viedokli par pētījuma jautājumiem brīvā formā. Vinu izteikumi satur vairāk nekā 13.000 vārdu (apmēram 45 lpp.).

Respondentu iesaistīšanās kvalitāte šajā pētījumā norāda uz tā aktualitāti un nepieciešamību. Pētījums veikts Latvijas likumdošanā ietverto vadlīniju par tikumisko audzināšanu Latvijas skolās (15.07.2016. MK noteikumi Nr. 480) kontekstā, ņemot vērā arī aktuālā izglītības satura reformas projekta "Skola2030" pamatnostādnes. Pētījuma jautājumi, kas prezentēti šajā ziņojumā, ir šādi: "Vai skolēnu morālā audzināšana ir daḷa no skolotāju lomas?", "Vai var sekmēt skolēnu rakstura veidošanos mācību stundās?", "Vai nepieciešams definēt attīstāmās rakstura īpašības skolas dokumentos?", "Vai skolām jāsekmē skolēnu morālo ieradumu veidošanās, vai tām jāfokusējas uz akadēmiskajiem sasniegumiem?", "Vai jaunie skolotāji tiek pienācīgi sagatavoti šim audzināšanas darbam?". Atvērtajos jautājumos respondenti atbildēja arī uz šādiem jautājumiem: "Kā veicināt skolēnu tikumiskā rakstura veidošanos?", "Kā sagatavot un atbalstīt skolotājus šim darbam?", "Kā sekmēt ǵimenes - skolas sadarbību šajā jomā?"

Pētījuma zinātniskā kvalitāte ir augsta - to veica Latvijas Zinātnes padomes eksperts, Pedagoğijas zinātniskā institūta vadošais pētnieks un bijušais direktors, Pedagogijijas zinātņu doktors Manuels Fernandezs sava pēcdoktorantūras projekta ietvaros. Pētījumā izmantota Demos pētîjumu aǵentūras (UK) izstrādātā un starptautiski validètā anketa, iegūta datu augsta ticamība, kas tika pārbaudīta, izmantojot zinātnisko metodi - Kronbaha alfa testu $(\alpha=, 827)$. Pètījums ir reprezentatīvs Latvijas un katra reǵiona mērogā, kā arī katrā no iepriekšminētajām respondentu grupām. Datu analīzē tika izmantota mūsdienīga programmatūra: "SPSS 22" kvantitatīvo datu analīzei, bet "NVivo 11 Plus" - respondentu izteikumu analīzei.

Ziṇojums strukturēts piecās daḷās: respondentu viedokḷu kopsavilkums (1/5) un vecāku (2/5), skolotāju (3/5), topošo skolotāju (4/5) un skolu un izglītības pārvalžu vadītāju (5/5) viedokḷi. Ziņojumā akcentētas kopējās tendences un statistiski nozīmīgās atšķirības starp reǵioniem un sektoriem, bet rezultāti tiek prezentēti lakoniski - bez interpretācijas. Tomēr pie rezultātiem minēti daži respondentu izteikumi, kas bagātīgi ilustrē galvenās tendences respondentu atbildēs.

Šis materiāls ir nozīmīgs ieguldījums Latvijas izglītības sistēmā esošo viedokḷu un vajadzību izpratnei skolēnu morālo ieradumu veidošanās jomā. Ziņojumā tiek piedāvāta vērtīga tēma personīgajām pārdomām un iespējas tās aktualizēšanai ǵimenē, skolotāju sanāksmēs, skolu vadītāju semināros un izglītības politikas veidotāju diskusijās, kā arī akadēmiskajiem mācībspēkiem, kuri nodarbojas ar skolotāju tālākizglītību un topošo skolotāju sagatavošanu.

Dr. Manuels Fernandezs

Rīgā 2019. gada martā 


\section{Galvenās tēzes}

- Vecāki ir galvenie atbildīgie par savu bērnu morālo audzināšanu. Viṇi nedrīkst delegeèt šo atbildību skolai vai skolotājiem, bet nepieciešama sadarbība.

- Savukārt skolai un skolotājiem ir svarīga loma skolēnu morālajā audzināšanā, ko nedrīkst ignorēt (viedokli atbalsta $77 \%$ no respondentiem). Katrā mācību stundā var mērḳtiecīgi sekmēt skolēna morālo ieradumu jeb rakstura veidošanos $(92 \%)$.

- Vecāku un skolotāju saskaņota sadarbība šajā jomā ir būtiska, lai bērnos nerodas apjukums. Vecāki vēlas no skolotājiem savlaicīgu informāciju un ieteikumus savu bērnu audzināšanai, bet skolotāji - vecāku aktīvu iesaistīšanos.

- Skolas vidē cilvēcisko attiecību kvalitātei un pieaugušo labajam piemēram (savstarpējai cieņai, godīgumam, rūpēm par citiem, centībai, izpalīdzībai) ir liela nozīme morālo vērtību nostiprināšanā jauniešu sirdī un prātā.

- Skolas vadības un visas sabiedrības atbalsts ir vajadzīgs, tomēr skolas iekšējās kārtības līmenī nav nepieciešams fiksēt skolēnu personības šablonu, jo katrs skolēns ir unikāla personība: skolēnu dažādība jāuztver kā bagātība.

- Augstskolās jāpiedāvā studiju kursi skolotāju sagatavošanas programmās un tālākizglītības kursi skolotājiem un vecākiem skolēnu morālo ieradumu veidošanās jomā. Tiem jābūt praktiskiem, balstîtiem uz reālām situācijām. İpaši svarīga arī ir pašu skolotāju personības pilnveide.

- Skolotājiem steidzami vajadzīgi metodiskie materiāli un metodiskie ieteikumi, kas saskaņoti ar izglītības satura reformas projektu Skola2030 un vadlīnijām par tikumisko audzināšanu Latvijas skolās (15.07.2016 MK. noteikumi Nr. 480).

Atsauce: Fernández González, M. J. (2019). Skolēnu morālā audzināšana Latvijas skolās: vecāku, skolotāju, topošo skolotāju un skolu un izglìtības pārvaldes vadītāju viedokḷi. Populārzinātniskais pētījuma ziṇojums. Rīga: Latvijas Universitātes Pedagoǵijas zinātniskais institūts. 


\section{İss glosārijs}

Temperaments: Noturīgs iedzimto vai agrīnā bērnībā veidoto personības īpašību kopums. Cilvēks neizvēlas savu temperamentu, bet to var pārvaldīt, iegūstot morālos ieradumus. Cilvēka personību veido temperamenta un rakstura īpašīîu kopums.

Raksturs: Morāli vērtējamo personības iezīmju kopums, ko veido cilvēka morālie ieradumi. Cilvēks ir atbildīgs par sava rakstura veidošanos, ko pats un ar līdzcilvēku palīdzību var pilnveidot visa mūža garumā.

Morālais ieradums: Brīvi un apzināti attīstīts un ar laiku nostiprināts izjušanas, domāšanas un rīcības veids, kas atbilst morālajām vērtībām un izpaužas jebkurā situācijā. Morālajos ieradumos balstītās uzvedības īpašības: spontānums, stabilitāte, piemērotība, vieglums un prieks tās izpildē, pat ja tas prasa piepūli. Sinonīms: tikums.

Morālās vērtības: priekšstats, izpratne par morālajiem labumiem. Audzināšanas vadlīnijās Latvijas skolām minētās vērtības ir: dzīivība, cilvēka cieņa, brīivība, gimene, laulība, darbs, daba, kultūra, latviešu valoda un Latvijas valsts. Vērtības ir pamats morālo ieradumu jeb tikumu veidošanai: tikumi atvieglo vērtību apliecināšanu un īstenošanu dzīvē.

Tikums: labs morālais ieradums, kas balstās uz apgūtām un sev pieņemtām vērtībām un mudina cilvēkam brīvi, dabiski un stingri stāties par morālo labumu un to īstenot jebkurā situācijā. Audzināšanas vadlīnijās minētie tikumi ir: atbildība, centība, drosme, godīgums, gudrība, laipnība, līdzcietība, mērenība, savaldība, solidaritāte, taisnīgums un tolerance.

Labs raksturs ietver sevī zināšanas par labo, tieksmi darīt labo un labu uzvedību - prāta, sirds un rīcības morālos ieradumus (Linkona, 1991).

\section{Satura rādītājs}

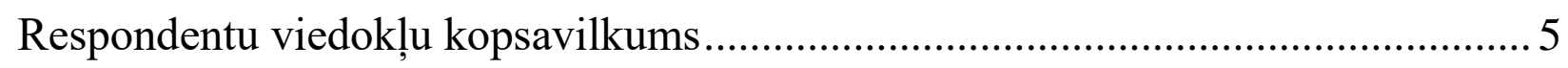

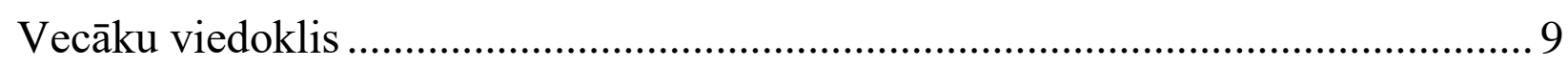

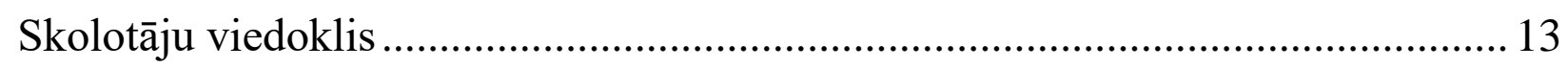

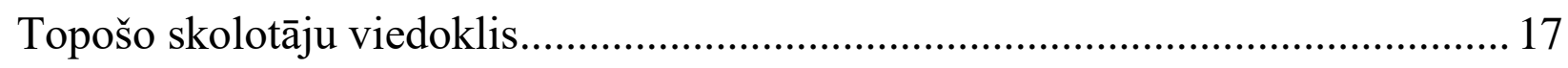

Skolu un izglītîbas pārvalžu vadītāju viedoklis ................................................. 21 


\title{
Skolēnu morālā audzināšana Latvijas skolās
}

\author{
Populārzinātnisks pētījuma ziņojums (1/5) \\ RESPONDENTU VIEDOKL,U KOPSAVILKUMS
}

Dr. Manuel Joaquín Fernández González

Latvijas Universitātes Pedagoǵijas, psiholoǵijas un mākslas fakultātes Pedagoǵijas zinātniskā institūta vadošais pētnieks Pēcdoktorantūras projekts "Izglîtības modernizācija Latvijas skolās, īstenojot inovatīvu pētniecībā balstītu programmu par 21. gadsimta kompetencēm un tikumu êtikas attīstību ar virtuālās telpas atbalstu (ARETE-school)" projekta Nr. 1.1.1.2/VIAA/1/16/071

Pētījuma konteksts. 2018. gadā tika veikts pētījums par skolēnu morālo ieradumu veidošanos skolās, kurā piedalījās vairāk nekā 2250 respondenti (skolēni, skolotāji, vecāki, topošie skolotāji, skolu un izglītības pārvaldes vadītāji) no visas Latvijas. Šajā ziņojumā prezentēts respondentu viedokḷu kopsavilkums par pētījuma jautājumiem, kas attiecas uz skolotāju lomu skolēnu morālajā audzināšanā un skolotājiem nepieciešamo atbalstu.

Par respondentiem. Atbildot uz šiem jautājumiem, pētījumā piedalījās 1351 respondenti no visiem sektoriem, izņemot skolēnus. $91 \%$ bija sievietes, jaunākajam respondentam bija 18 gadi, bet vidējais vecums bija 41 gads. Lielākā daḷa no respondentiem bija no Rīgas $(40 \%)$, bet pētījumā tika labi pārstāvēti visi Latvijas reǵioni.

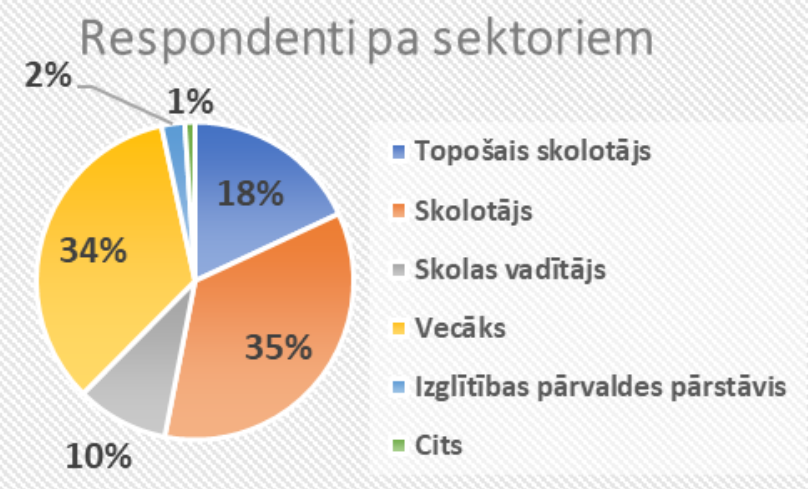

\section{Respondenti pa regioniem}

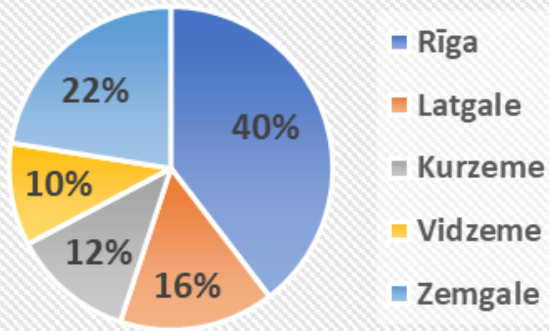

70\% no respondentiem uzskatīja, ka skolēnu morālā audzināšana ir daḷa no skolotāju lomas (Vai Jūs domājat, ka skolēna morālā audzināšana ir daḷa no skolotāju lomas?)

Vai morālā audzināšana ir ? dala no skolotāja lomas?

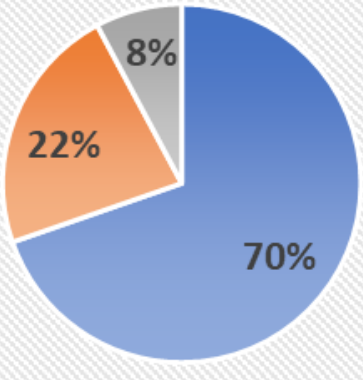

- JĀ, tā ir skolotāja atbildība

- NĒ, tā nav skolotāja atbildība

- Man nav viedokla
$70 \%$ no respondentiem uzskatīja, ka skolēna morālā audzināšana ir daḷa no skolotāju lomas, un tikai $22 \%$ nepiekrita tam. Kā norādīja viens no vecākiem, "bērni loti daudz laika pavada izglìtības iestādē (dažkārt pat vairāk nekā ar gimeni sanāk). Tādēl ir būtiski, lai skola iesaistās bērna rakstura audzināšanā". Atškirirības starp sektoriem ir statistiski nozīmīgas $(\mathrm{p}=, 000)$ : studentu proporcija, kuri uzskatīja, ka tā ir dala no vinuu lomas, bija vislielākā (86\%), bet vecāki visretāk domāja, ka tā ir daḷa no skolotāju lomas (56\%). Kāds skolotājs precizēja, " $J \bar{a}, t \bar{a}$

ir daḷa no manas lomas, bet ne mana atbildība." Reǵionālās atškirīibas arī ir statistiski nozīmīgas: $(p=, 010)$ : Rīgā un Latgalē proporcija bija visaugstākā $(73 \%)$, bet Kurzemē viszemākā (58\%). 


\section{2\% no respondentiem uzskatīja, ka var sekmēt skolēnu rakstura veidošanos} mācību stundās

Kuram no šiem diviem apgalvojumiem Jūs visvairāk piekrītat?

- VAR mācìt beerniem vērtības un palīdzèt viniem pilnveidot savu raksturu skolā mācību stundās ar komandas darba uzdevumiem vai iesaistot bērnus brīvprātīgajā darbā

- NEVAR palīdzēt bèrniem pilnveidot savu raksturu skolā, mācot šo tēmu mācību stundās; viñi vienkāršsi mācīsies to no citiem skolēniem un skolas pieredzes

\section{Vai iespējams sekmèt rakstura veidošanos mācibu stundās?}

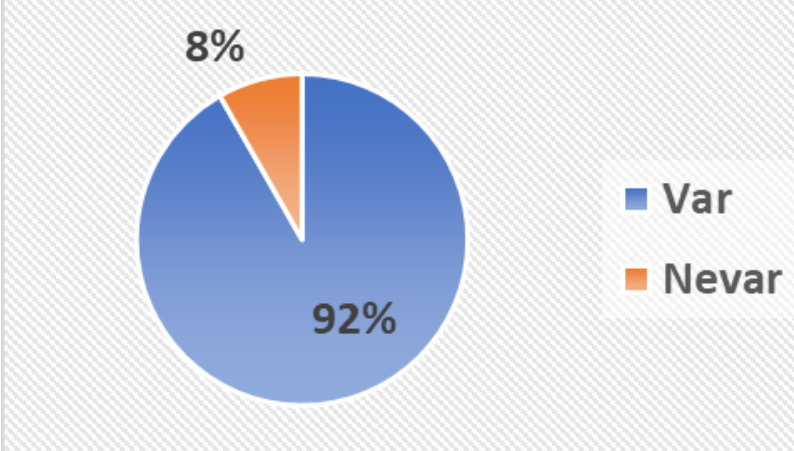

Gandrīz visi respondenti $(92 \%, \mathrm{~N}=1208)$ uzskatīja, ka ir iespējams sekmēt skolēnu morālo ieradumu veidošanos mācību stundās. Tikai $8 \%$ nepiekrita tam. Reǵionālo un sektoru atškirīību šajā jautājumā nepastāv. Kāds skolas vadītājam bija svarīgi uzsvērt "mācību un audzināšanas darba vienotību skolas ikdienas procesā". Kā atzīmēja kāds skolotājs, "jebkurā mācību stundā, arī starpbrīžos, kopīgajos pasākumos, ekskursijās tiek runāts, pārrunāts, radīta vide, lai skolēnos veidotos izpratne par vērtībām". Cits skolotājs uzskatīja, ka "katra mācību stunda ir arī skolēna rakstura veidošanās, tāpēc uzsvars, sevišķi sākumskolā, jāvelta skolēnu audzināšanai".

\section{4\% no respondentiem uzskatīja, ka nav nepieciešams definēt attīstāmās} rakstura īpašības skolas dokumentos (Vai Jūs domājat, ka katras skolas dokumentos vajag skaidri definèt galvenās rakstura īpašìbas, ko tā vēlas attīstīt savos skolēnos?)

Kopumā, vairākums no respondentiem (44\%, N=584) uzskatīja, ka nav nepieciešams definēt attīstāmās rakstura ipašības skolas dokumentos, bet atškirīības starp sektoriem ir statistiski nozīmīgas $(\mathrm{p}=, 002)$ : studentu un izglìtības pārvaldes darbinieku proporcija, kuri uzskatīja, $\mathrm{ka}$ to vajag iekḷaut skolas dokumentos, bija vislielākā (respektīvi $41 \%$ un $42 \%$ ), bet skolotājiem un skolas vadītājiem visbiežāk bija pretējs viedoklis (48\%). Reǵionālās atškịīības arī ir l,oti nozīmīgas $(p<, 000)$ : Zemgalē respondentu proporcija, kuri uzskatīja, ka nav nepieciešams norādīt vēlamās rakstura īpašības skolas dokumentos, bija vislielākā (55\%), bet Vidzemē vairākums respondentu uzskatīja, ka to vajadzētu darīt (40\% pret $29 \%$, kuri uzskatīja, ka nevajag). Viens students norādīja, ka "skolēnu rakstura ìpašības ir individuāla lieta un tās nav jāreglamentē skolas iekšèjās kārtības lìmenī. Tas izveidotu noteiktu "rakstura ideālu", kuram visiem būtu jāatbilst, un tas nav pareizi.". Savukārt viens vecāks komentēja, ka "skolā ir definètas vērtības, skola kopā ar vecākiem kopīgi ir paveikusi vērtību definēšanas darbu, un šobrīd skolā dažādos veidos tās tiek ieviestas dzīve"’. 


\section{$77 \%$ no respondentiem uzskatīja, ka skolām jāsekmē skolēnu izpratne par} vērtībām un jāveicina skolēnu rakstura veidošanās

Kuram no šiem diviem apgalvojumiem Jūs visvairāk piekrïtat?

- Skolām jāattīsta skolēnu raksturs un jāveicina labas vērtības savos skolēnos

Vai skolai jārūpējas par skolēnu rakstura veidošanos?

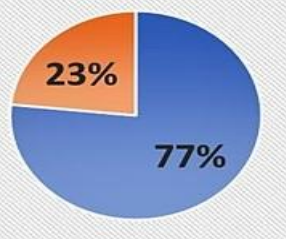

- Skolām jāfokusējas uz akadēmisko darbu, nevis jāveido skolēnu raksturs

\section{Izvēlētie izskaidrojumi (N)}

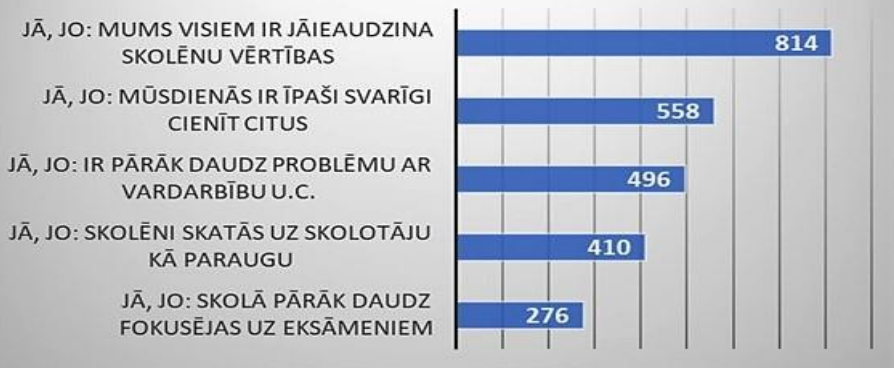

Izvēlētie izskaidrojumi (N)

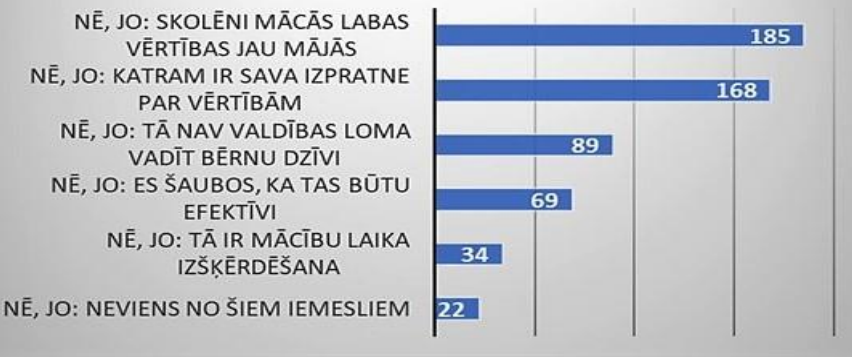

Kopumā $77 \%$ no respondentiem $(\mathrm{N}=1009)$ piekrita tam, ka skolām jāattīsta skolēnu raksturs un jāveicina labas vērtības savos skolēnos. Atškịīības starp sektoriem ir statistiski nozīmīgas $(\mathrm{p}=, 000)$ : vadītāju un studentu vidū proporcija bija vislielākā (respektīvi - 86\% un $84 \%$ ). Kā komentēja jauna studente, "pirmskolās un skolās vajag vairāk pievērst uzmanību bērna tikumiskajai audzināšanai, stāstīt bērniem par attiecūbām ar cilvēkiem, ieaudzināt mūlestību pret pasauli. Tas ir grūti, bet tomēr vajag vairāk par to runāt un rādīt ar savu piemēru". Vecāku vidū proporcija tomēr bija zemāka (66\%). Viens no vecākiem savu atbildi komentēja šādi: "Neuzskatu, ka tā ir skolas atbildība. Negaidu to no skolas. Savu bērnu rakstura audzināšana, pirmkārt, ir mana - kā vecāka - atbild̄̄ba. Tikai tad skola, skolotāji, un pienemu - atbilstošā situācijā vini to dara. Paldies viniem par to!" Visbiežāk izvēlētie pamatojumi šim viedoklim bija - "mums visiem ir jāieaudzina skolēnu vērtības" (32\% no izvēlēm, N=814) un "mūsdienās ir ìpaši svarīgi cienīt citus" (22\%). Kopumā tikai $22 \%$ no respondentiem uzskatîja, ka skolām jāfokusējas uz akadēmisko darbu, un viṇu visbiežāk izvēlētie pamatojumi bija - "skolēni mācās labas vērtības jau mājās" (33\%, N=185) un "katram ir sava izpratne par vērtībām" (30\%). Šajā jautājumā nozīmīgo reǵionālo atškirirību nav.

Respondentiem (izṇemot vecākus; N=706), kuri uzskatīja, ka skolai jāsekmē skolēnu rakstura veidošanās, tika jautāts: "Vai skolotāji tiek labi sagatavoti skolēnu rakstura audzināšanai?" Kopumā 28\% (N=217) uzskatīja, ka vinii ir drīzāk, pietiekami vai pilnīgi sagatavoti šim darbam, bet atšksirības starp sektoriem ir statistiski loti nozīmīgas $(\mathrm{p}=, 000)$ : studenti un skolotāji visbiežāk bija pārliecināti par savu sagatavotību (respektīvi - 68\% un 58\%), bet tikai $25 \%$ no skolas vadītājiem un 16\% no izglītības pārvaldes pārstāvjiem domāja, ka skolotāji ir sagatavoti. Reǵionālo atšḳirību nav.

\section{Vai skolotāji tiek sagatavoti skolēnu rakstura audzināšanai?}

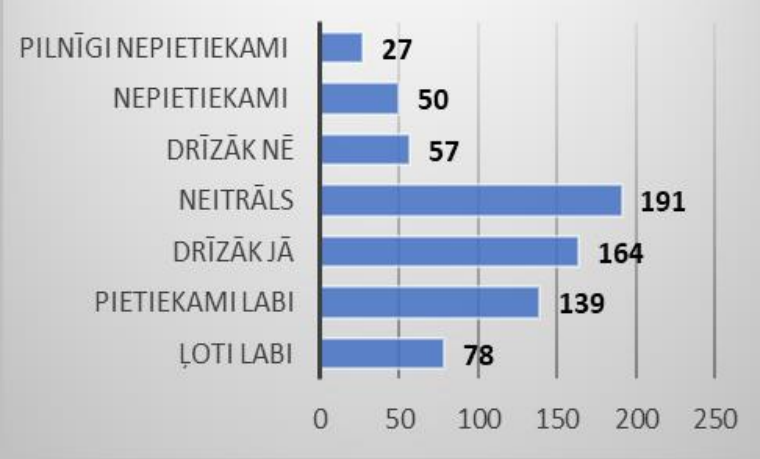




\section{Respondentu ieteikumi skolēnu morālo ieradumu veidošanās sekmēšanai skolās. Skolotāju sagatavošana un nepieciešamais atbalsts}

Respondenti brīvā formā izteicās par to, kā labāk sekmēt skolēnu tikumiskā rakstura , un sagatavot un atbalstīt skolotājus šim darbam. Kopumā viņu izteikumi satur vairāk nekā 13000 vārdus. Aizpildot anketu, respondentiem netika piedāvāti atbilžu izvēles varianti, bet katrs respondents ieteica pats to, kas viņam šķita vajadzīgs vai nozīmīgs. Šajā kopsavilkumā minētas galvenās tēmas, bet respondentu komentārus var lasīt katra sektora ziņojumā.

Galvenais ieteikums no visiem sektoriem bija veidot ciešāku sadarbību ar ǵimenēm, jo gimenes vislabāk pazīst savus bērnus un lai bērnam neradītu apjukumu, ka mājās viṇu audzina vienā veidā, bet skolā citādāk. Šajā sadarbībā var rasties grūtības atšķiirīgu uzskatu dēḷ. Labas sadarbības prakses piemēri ir individuālās pārrunas starp vecākiem un skolotājiem, vecāku regulāra un savlaicīga informēšana par bērna pozitīvām un pilnveidojamām pusēm un skolotāju ieteikumi vecākiem. Vecākus varētu arī iesaistīt radoši, piemēram, plānojot (kā daḷu no skolēnu mājas darbiem) diskusijas gímenē par morālo audzināšanu.

Skolotājiem ḷoti noderētu metodiskie materiāli, kas izmantojami darbam klasē (īpaši bieži pieminētas ir īsfilmiņas, darba lapas, situācijas vai dilemmas diskusiju veicināšanai klasē un mācību plāni audzināšanas stundām), metodiskie ieteikumi (t.sk., pedagoǵiskā literatūra, tikumu definīcijas un pētījumi), bet tiem būtu jābūt praktiskiem, balstītiem uz reālām situācijām, kā arī kursi.

Jauno skolotāju sagatavošanā divas galvenās tēmas bija prakses un pieredzes nepieciešamība un vajadzība pašiem skolotājiem attīstīt savu personību, jo no paša skolotāja rakstura iezīmēm būs atkarīgs tas, kā viņš vai viņa spēs atbalstīt skolēnu pilnveidi. Respondenti uzskatīja, ka parasti jaunajiem skolotājiem piemīt spēja labāk izprast skolēnus un veidot labas attiecības ar viṇiem, bet tas nav vienmēr tā. Turklāt skolotāji nāk uz skolu ar jau izveidojušos personību. Tādēḷ kvalitatīva jauno skolotāju atlase ir svarīga.

Respondenti bieži minēja arī speciālistu (psihologa, sociālā darbinieka) atbalsta nepieciešamību un vēlmi sadarboties ar citiem kolēǵiem, it īpaši pieredzes bagātiem skolotājiem. Daudzi respondenti uzskatīja, ka ir nepieciešams skolas vadības un sabiedrības atbalsts. Nobeigumā vairāki respondenti uzsvēra šì pētījuma nozīmīgumu un aktualitāti, kā arī morālās audzināšanas pozitīvo ietekmi mācību procesā.

\section{ĪSS IESKATS PĒTİJUMA METODOLOGIJĀ}

Pētījuma datu vākšanai izmantota starptautiski validèta anketa, ko 2015. gadā izveidoja ievērojamā Demos pētījumu aǵentūra (UK) un kas tika tulkota latviešu valodā un pilotēta 2018. gada sākumā. Datu vākšana notika no 2018. marta līdz 2018. novembrim sadarbībā ar visu Latvijas novadu izglītības pārvaldēm, kā arī atseviškiiem skolas direktoriem, skolotājiem un gímenes biedrībām. Tika analizētas 847 anketas papīra formātā un 1341 elektroniskās anketas.

Pētījuma ticamība un reprezentativitāte (pēc Fisher, Arkin, \& Colton, 1995). Iegūto datu ticamība tika pārbaudīta, izmantojot Kronbaha alfa testu. Datu ticamības lìmenis ir loti augsts: $(\alpha=, 827)$. Latvijas izglîtības sistēmas mērogā pêtījums ir reprezentatīvs, pieḷaujot $2 \% \mathrm{kḷūdu}$ rezultātos. Pētījuma reǵionālās reprezentativitātes līmenis arī ir augsts: Rīgā ar 4.5\% kḷūdu rezultātos, Zemgalē - 5,5\%, Latgalē $-7 \%$, bet Kurzemē un Vidzemē $-8 \%$. Pètījums arī ir reprezentatīvs šādos sektoros (ar šādu \% kḷūdu rezultātos): 9. un 12. klases skolēniem (3,5\%), topošajiem skolotājiem (5,5\%), skolotājiem (4,5\%), skolu vadītājiem (8\%) un vecākiem (4,5\%).

Kvantitatīvo datu apstrāde un analīze tika veikta, izmantojot MS Excel un SPSS_22 programmatūru (Chi kvadrāts, Phi un Cramers' V testi izmantoti sektoru un reǵionu atšķirīibu izpētei). Kvalitatīvo datu apstrādei izmantota programmatūra NVivo 11 Plus.

Vairāk informācijas par pētījumu: manuels.fernandezs@lu.lv $\quad$ Rīgā

2019. gada martā 


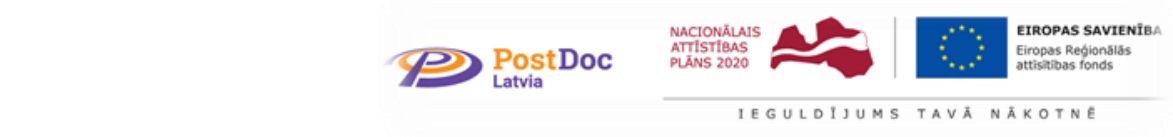

\title{
Skolēnu morālā audzināšana Latvijas skolās
}

\author{
Populārzinātnisks pētījuma ziṇojums (2/5) \\ VECĀKU VIEDOKLIS

\section{Dr. Manuel Joaquín Fernández González}

\begin{abstract}
Latvijas Universitātes Pedagogiijas, psiholoǵijas un mākslas fakultātes Pedagoǵijas zinātniskā institūta vadošais pētnieks Pēcdoktorantūras projekts "Izglīīības modernizācija Latvijas skolās, īstenojot inovatīvu pētniecībā balstītu programmu par 21. gadsimta kompetencēm un tikumu ètikas attīstību ar virtuālās telpas atbalstu (ARETE-school)" projekta Nr. 1.1.1.2/VIAA/1/16/071
\end{abstract}

Pētījuma konteksts: 2018. gadā tika veikts pētījums par skolēnu morālo ieradumu veidošanos skolās, kurā piedalījās vairāk par 2250 respondentiem (skolēni, skolotāji, vecāki, topošie skolotāji, skolu un izglītības pārvaldes vadītāji) no visas Latvijas. Šajā ziņojumā prezentēts vecāku viedoklis par pētījuma jautājumiem, kas attiecas uz skolas un skolotāju lomu skolēnu morālajā attīstīšanā.

\section{Respondenti pa reǵioniem}

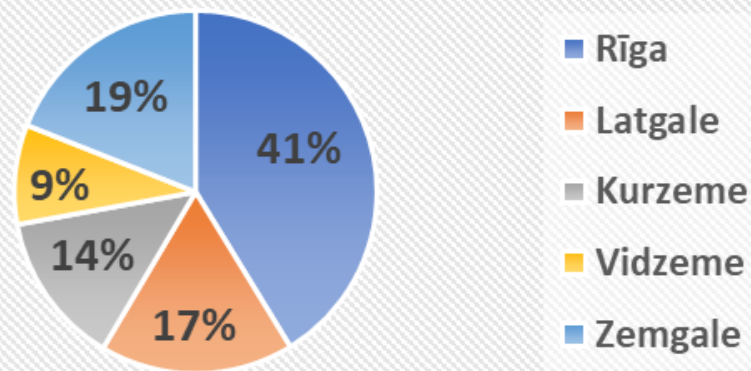

\section{Par respondentiem}

Pêtījumā piedalījās 463 vecāki (89\% sievietes). Jaunākajam respondentam bija 27 gadi, bet vidējais vecums bija 41 gads. Lielākā dậa no respondentiem (41\%) bija no Rīgas, bet pêtījumā tika pārstāvēti visi Latvijas regioni. Respondentu sociālekonomiskais statuss bija pārsvarā vidējs vai augstāks par vidējo $(79 \%)$.

56\% no vecākiem uzskatīja, ka skolēnu morālā audzināšana ir daḷa no skolotāja lomas

Vai Jūs domājat, ka skolēna morālā audzināšana un vērtību audzināšana ir daḷa no skolotāja lomas?

\section{Vai rakstura audzināšana ir dala} no skolotajulomas?

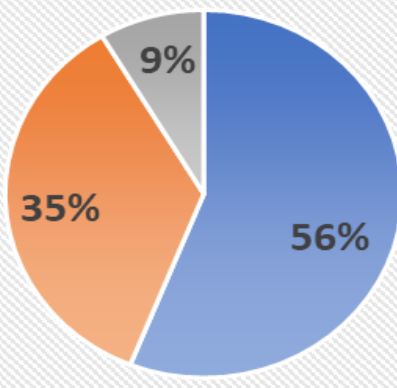

- JĀ, tā ir skolotāju atbildība

nĒ, tā nav skolotāju atbildība

- Nav viedok!̣a
56 \% no aptaujātajiem vecākiem uzskatīja, ka skolēna morālā audzināšana un vērtību audzināšana ir daḷa no skolotāja lomas. Rīgā šñ proporcija bija vēl lielākā (61,6 \%). Kā norādīja viens no vecākiem, "bērni l, loti daudz laika pavada izglìtības iestādē (dažkārt pat vairāk nekā ar gimeni sanāk). Tādēl ir būtiski, lai skola iesaistās bērna rakstura audzināšanā". Kopumā apmēram tikai trešdaḷa no vecākiem nepiekrita tam. 


\section{2\% no vecākiem uzskatīja, ka var sekmēt skolēnu rakstura veidošanos mācību stundās}

Kuram no šiem diviem apgalvojumiem Jūs visvairāk piekrìtat?

- VAR mācìt bērniem vērtības un palīdzēt viniem pilnveidot savu raksturu skolā mācību, ar komandas darba uzdevumiem vai iesaistot bērnus brīvprātīgajā darbā

- NEVAR palīdzēt bērniem pilnveidot savu raksturu skolā, mācot šo tēmu mācību stundās; vini vienkāršsi mācīsies to no citiem skolēniem un skolas pieredzes

\section{Vai iespējams sekmēt rakstura veidošanos mācibu stundās?}

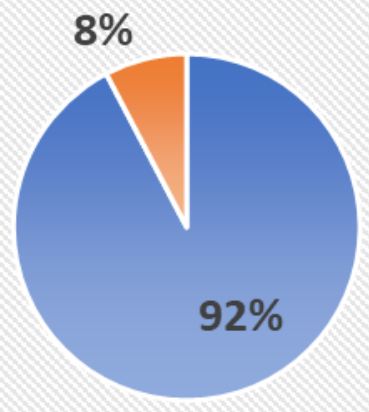

- Var

Nevar

Gandrīz visi aptaujātie vecāki $(92 \%, N=420)$ uzskatīja, ka ir iespējams sekmēt skolēnu morālo ieradumu veidošanos mācību stundās. Tikai $8 \%$ nepiekrita tam. Š̄̄ vecāka izteiciens labi ilustrē kopējo tendenci: "Klases audzinātāja regulāri izrunāa š̄is tēmas ètikas stundās, kā arī izklāsta savu vīziju un iespējamās problēmsituācijas vecāku sapulcēs. Pievēršs uzman̄̄bu morālām vērtībām, runā un skaidro to skolēniem. Iespējams, ka citi skolotāji tā nedara, bet mums vienkārši paveicās". Daži vecāki uzsvēra, ka metodēm jābūt piemērotām, un tās var būt dažādas: "Būtu nepieciešama stunda vai nodarb̄̄ba, kurā tiktu izrunāts ar piemēriem, filmin̄àm un citiem uzskates līdzekl̦iem par skolēnu savstarpējo cien,u, cieņu pret skolotāju, pret savām un citām lietām (mācību, apgēerbu utt.)".

\section{$43 \%$ no vecākiem uzskatīja, ka nav nepieciešams definēt attīstāmās rakstura īpašības skolas dokumentos}

Vai Jūs domājat, ka katras skolas dokumentos vajag skaidri definèt galvenās rakstura īpašības, ko tā vēlas attīstīt savos skolēnos?

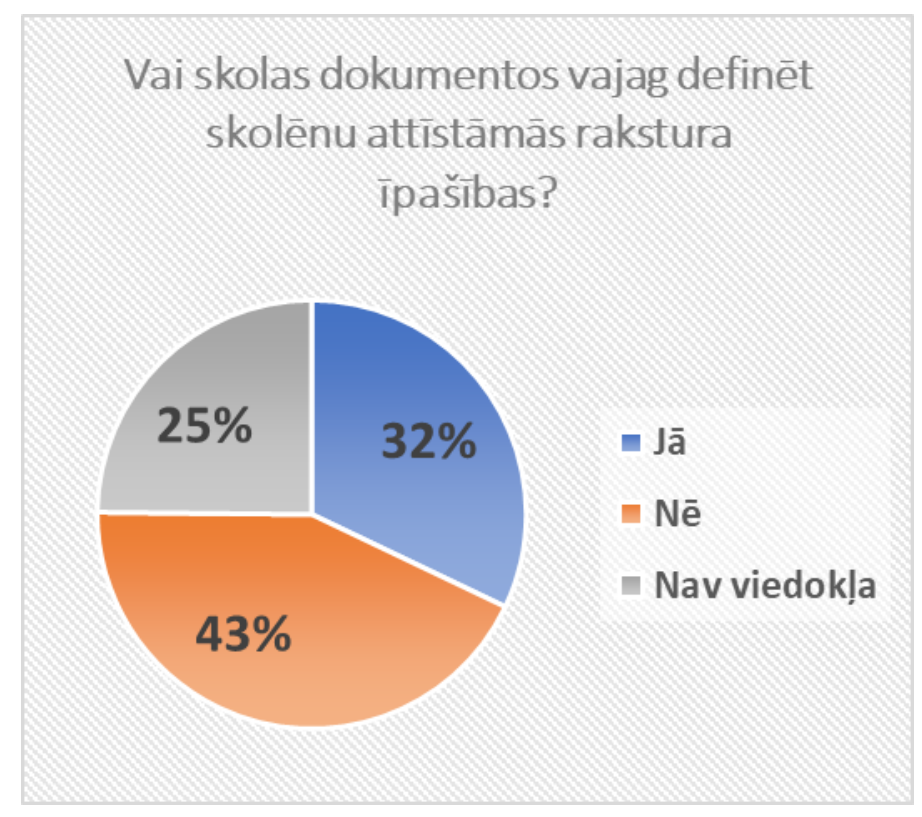

Kopumā, vairākums no vecākiem (43\%, $\mathrm{N}=196)$ uzskatīja, ka nav nepieciešams definēt attīstāmās rakstura īpašīibas skolas dokumentos. Tomēr reǵionālās atškirīibas šajā jautājumā ir statistiski nozīmīgas $(\mathrm{p}=0,047)$ : Latgalē un Zemgalē proporcija bija lielākā (respektīvi - 51\% un $57 \%$ ), bet Rīgā vairākums vecāku uzskatīja, ka to vajag darīt (40\% pret $37 \%$, kas uzskatīja, ka nevajag). Kā norādīja viens vecāks, "skolā ir definètas vērtības, skola kopā ar vecākiem kopīgi ir paveikusi vērtību definēšanas darbu, un šobrīd skolā dažādos veidos tās tiek ieviestas dzīve”. 


\section{Divas trešdaḷas no vecākiem uzskatīja, ka skolām jāsekmē skolēnu izpratne par vērtībām un jāveicina skolēnu rakstura veidošanās}

\section{Kuram no šiem diviem apgalvojumiem Jūs visvairāk piekrītat?}

- Skolām jāattīista skolēnu raksturs un jāveicina labas vērtības savos skolēnos

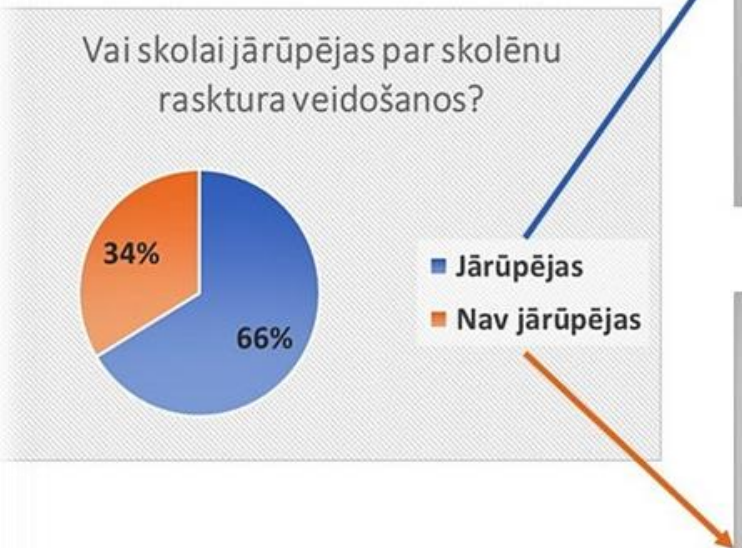

- Skolām jāfokusējas uz akadēmisko darbu, nevis jāveido skolēnu raksturs

\section{Izvēlētie izskaidrojumi (N)}
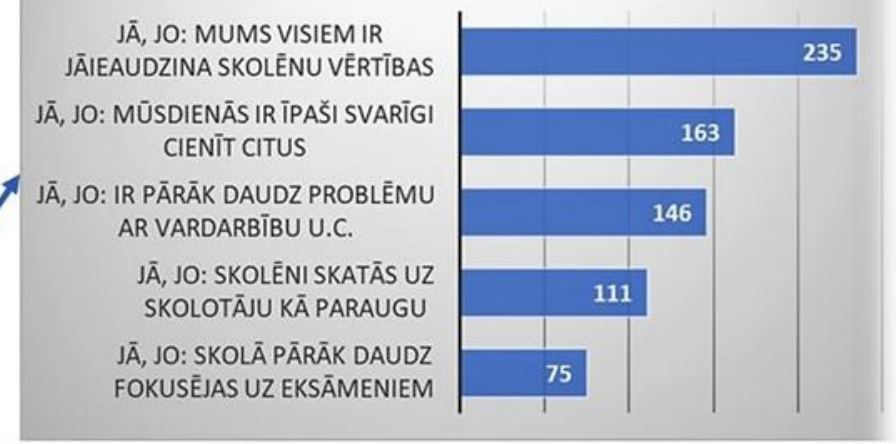

\section{Izvēlētie izskaidrojumi (N)}

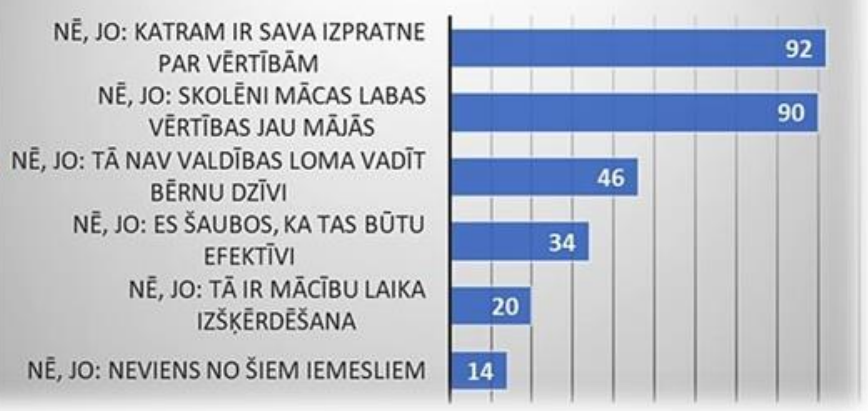

Kopumā, 66 \% no vecākiem $(\mathrm{N}=300)$ visvairāk piekrita tam, ka skolām jāattīsta skolēnu raksturs un jāveicina labas vērtības savos skolēnos. Rīgā tā proporcija bija vēl lielāka (70\%). Visbiežāk izvēlētie pamatojumi šim viedoklim bija - "mums visiem ir jāieaudzina skolēnu vērtības" (32\% no izvēlēm, $\mathrm{N}=235)$ un "mūsdienās ir îpaši svarīgi cienūt citus" (22\%). Trešdaḷa respondentu uzskatīja, ka skolām jāfokusējas uz akadēmisko darbu, un viṇu visbiežāk izvēlētie pamatojumi bija - "katram ir sava izpratne par vērtībām" (31\%, N=92) un "skolèni mācās labas vērtības jau mājās" (30\%). Kā komentēja viens no vecākiem, "neuzskatu, ka tā ir skolas atbild̄̄ba. Negaidu to no skolas. Savu bērnu rakstura audzināšana, pirmkārt, ir mana - kā vecāka-atbildūba". Tikai tad skola, skolotāji, un pieñemu - atbilstošă situācijā viņi to dara. Paldies viniem par to!"

\section{4\% no vecākiem uzskatīja, ka skola sadarbojas bērnu rakstura audzināšanā}

\section{Vai skola sadarbojas ar Jums kä vecākiem šajà jomâ?}

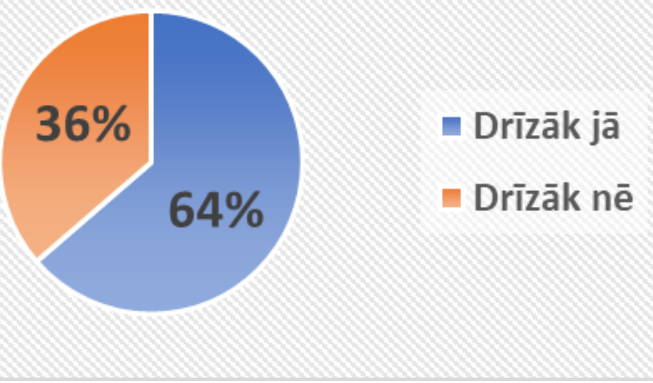

Vai šobrīd skola sadarbojas ar Jums kā vecākiem

Jūsu bērnu rakstura audzināšanas jomā?

- Drīzāk JĀ, sadarbība ir laba un diezgan regulāra šajā jomā.

- Drīzāk NÉE, sadarbība šajā jomā nenotiek vai notiek loti reti.

Kopumā trešdaḷa no vecākiem $(64 \%, N=191)$ uzskatīja, ka skola sadarbojas ar viniem bērnu rakstura audzināšanas jomā. Bet reǵionālas atškirīibas šajā jautājumā ir loti izteiktas ( $\mathrm{p}<, 000)$. Pozitīva sadarbība visbiežāk minēta Latgalē un Zemgalē (respektīvi - 83\% un $78 \%$ ), bet visretāk - Rīgā un Vidzemē (52\%). 


\section{Labās sadarbības piemēri un ieteikumi labākai sadarbībai vecāku izteikumos}

Vecāki brīvā formā izteicās par labas un nepietiekamas sadarbības konkrētiem piemēriem. Kopumā viṇu izteikumi satur vairāk nekā 4500 vārdus. Te tika apkopoti nozīmīgākie ieteikumi.

Vecākiem, kuri atzīmēja labu sadarbību ar skolu, tika jautāts: "Vai Jūs varat dalīties savā labajā pieredzēe? Lüdzu, aprakstiet to!’. Analīzē tika fiksēti 102 izteikumi, kuros aprakstīti labas sadarbības piemēri. Visbiežāk minēti pozitīvie piemēri attiecas uz to, ka notiek individuālās pārrunas starp vecākiem un skolotājiem (28\%) un ka informācija pie vecākiem nonāk regulāri un savlaicīgi (21\%), t.sk. caur e-klasi. Daloties ar savu labo pieredzi, kāds vecāks norādīja, ka būtiskākais šajā sadarbībā - "Klases audzinātājas nenogurstošais darbs, kur ik mirkli tiek pārrunātas situācijas, tās [tiek] analizētas un projicētas, kā citādāk iespējams rīkoties. Vai izcel̦ot un paspilgtinot pozit̄̄vās situācijas ar uzslavu u.tml. Paldies klases audzinātajai!’. Vecāki arī augstu novērtēja, ka skolā problēmas tiek parunātas (12\%) un skolotājs iesaka idejas vecākiem (7\%). "Regulāri notiek tikšanās ar pedagogiem, kuri sniedz informāciju par saviem novērojumiem bērna uzvedībā, dalās ar pieredzi un sniedz ieteikumus, kam vajadzētu pievērst uzman̄̄bu bērna personības attīstības jautājumā". Kā citi labas sadarbības piemēri tika minēti vecāku iesaistǐšana skolas pasākumos, skolotāja iesaistīšanās konfliktsituāciju risināšanā, skolēnu izaugsmes žurnāls un skolas atbalsta grupa.

Vecāki uzskatîja, ka skolotāju attieksme ir izšķiroša šajā sadarbībā, un tā tika identificēta $17 \%$ no reg̣istrētajiem labas prakses izteikumiem. Starp uzslavētājām attieksmēm, kas sekmē sadarbību ar vecākiem, īpaši atzīmēta skolotāju atsaucība (47\% no izteikumiem par skolotāju attieksmi), kā arī uzmanība pret bērniem (18\%). "Mūsu klases audzinātāja lieliski prot pateikt vēlamo un aizrādīt par nevēlamo gan tieši, gan "caur puk̄ēm", gan ar humoru." Citas vecāku minētās pedagogu īpašības, kas sekmē labu sadarbību ar skolu, bija skolotāju saprātīgums, atbildības izjūta, sirsnība un taisnīgums.

Vecākiem, kuri atzīmēja, ka sadarbība ar skolu nenotiek, tika jautāts: "Ko Jūus gaidītu vēl no skolas šajā jomāe? Lūdzu, uzrakstiet Jūsu ieteikumus labākai sadarbībai!’. Analīzē tika fiksēti 36 ieteikumi vai vecāku vēlmes šajā jomā. Vairākums vecāku vēlētos saṇemt regulārāku informāciju (44\%) un organizēt vairāk individuālas sarunas ar klases audzinātāju (17\%). Vecāki arī vēlētos saņemt ieteikumus no audzinātājiem (14\%), bērna audzināšanas jautājumu saskaņošanu ar viṇiem (11\%). Šī vecāka izteikums labi atspoguḷo šīs respondentu grupas domas: "Skolā loti reti notiek reāls audzināšanas darbs, parasti jebkāda sadarbība ar vecākiem (un arī audzināšanas darbs vecāki - skolēns) tiek veikta tikai ārkārtas situācijās, kad vadzis jau ir lüzis un vajag glābt sekas. No skolas daudz biežāk vēlētos redzèt reālus pasākumus / informāciju / iespēju redzèt to, kas skolā tiek darìts tajā jomā, kas veicina bērna raksturu, nevis tikai akadēmiskās zināšanas, piemēram, pulcinu apmeklējums, "piezīmes"/ komentāri par darbu skolā, klasēe ārpusskolas aktivitātēs. Kas tiek runāts audzināšanas stundās? Vai ir kādi jautājumi mana bērna raksturā, kuriem man kā vecākam bütu jāpievērš uzman̄̄ba, kamēr vadzis vēl nav lūzis? Kāda ir klases iekšèjā dinamika / sadarbība starp skolēniem? Vai ir projekti / pasākumi, kuros veidojas un izpaužas mana bērna sadarbība skolēns - vecāki un skolēns - skolēns? Man šădas informācijas nav jeb, labākajā gadījumā es to saṇemu tikai no sava bērna (tikai vina viedoklis)."

Cits vērtīgs ierosinājums bija iesaistīt vecākus diskusijās par tēmām, kas skar jauniešu morālo audzināšanu, plānot to kā daḷu no skolēnu mājas darbiem: "Manuprāt, mājas darbu izpilde ir jāorganizē tā, lai sociālo zin̄̄bu tèma izraisa diskusiju mājās. Un šai iniciatīvai ir jānāk no skolas. Pusaudzim vecāki vairs nepateiks - parādi, kas Tev uzdots, pastāsti, kā Tu to saproti utt."

Vairāk informācijas par pētüjumu: manuels.fernandezs@lu.lv $\quad$ Rīgā

2019. gada martā 


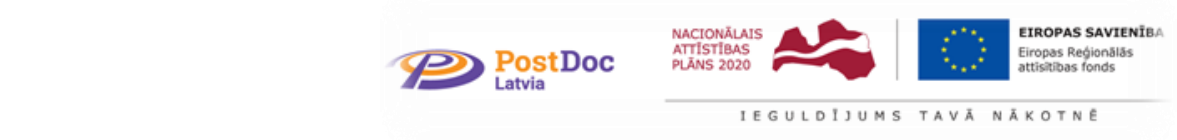

\title{
Skolēnu morālā audzināšana Latvijas skolās
}

\author{
Populārzinātnisks pētījuma ziṇojums (3/5) \\ SKOLOTĀJU VIEDOKLIS
}

\author{
Dr. Manuel Joaquín Fernández González
}

\begin{abstract}
Latvijas Universitātes Pedagogiijas, psiholoǵijas un mākslas fakultātes Pedagoǵijas zinātniskā institūta vadošais pētnieks Pēcdoktorantūras projekts "Izglîtības modernizācija Latvijas skolās, īstenojot inovatīvu pētniecībā balstītu programmu par 21. gadsimta kompetencēm un tikumu ètikas attīstību ar virtuālās telpas atbalstu (ARETE-school)" projekta Nr. 1.1.1.2/VIAA/1/16/071
\end{abstract}

Pētījuma konteksts. 2018. gadā tika veikts pētījums par skolēnu morālo ieradumu veidošanos skolās, kurā piedalījās vairāk nekā 2250 respondenti (skolēni, skolotāji, vecāki, topošie skolotāji, skolu un izglītības pārvaldes vadītāji) no visas Latvijas. Šajā ziņojumā prezentēts skolotāju viedoklis par pētîjuma jautājumiem, kas attiecas uz skolotāju lomu skolēnu morālajā audzināšanā un viniiem nepieciešamo atbalstu.

\section{Respondenti pa reǵioniem}

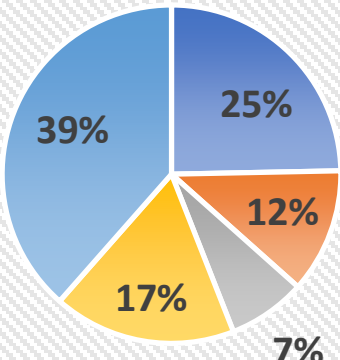

$7 \%$

\section{Par respondentiem}

Pētījumā piedalīīâs 473 skolotāji, 95\% bija sievietes. Jaunākajam respondentam bija 23 gadi, bet vidējais vecums bija 48 gadi. Lielākā daḷa no respondentiem bija no Zemgales (38\%) un no Rīgas (25\%), bet pētījumā tika pārstāvēti visi Latvijas reǵioni. Respondentu vidējais darba stāžs bija 24 gadi, bet $10 \%$ no viṇiem stāžs bija mazāks par 5 gadiem. Tika pārstāvēti visi izglītības posmi un mācību priekšmeti, bet visbiežāk - matemātika, sociālās zinības, latviešu valoda, dabaszinības, māksla un ētika.

73\% no skolotājiem uzskatīja, ka skolēnu morālā audzināšana ir daḷa no viṇu lomas (Vai Jūs domājat, ka skolēna morālā audzināšana un vērtību audzināšana ir daḷa no Jūsu lomas?)

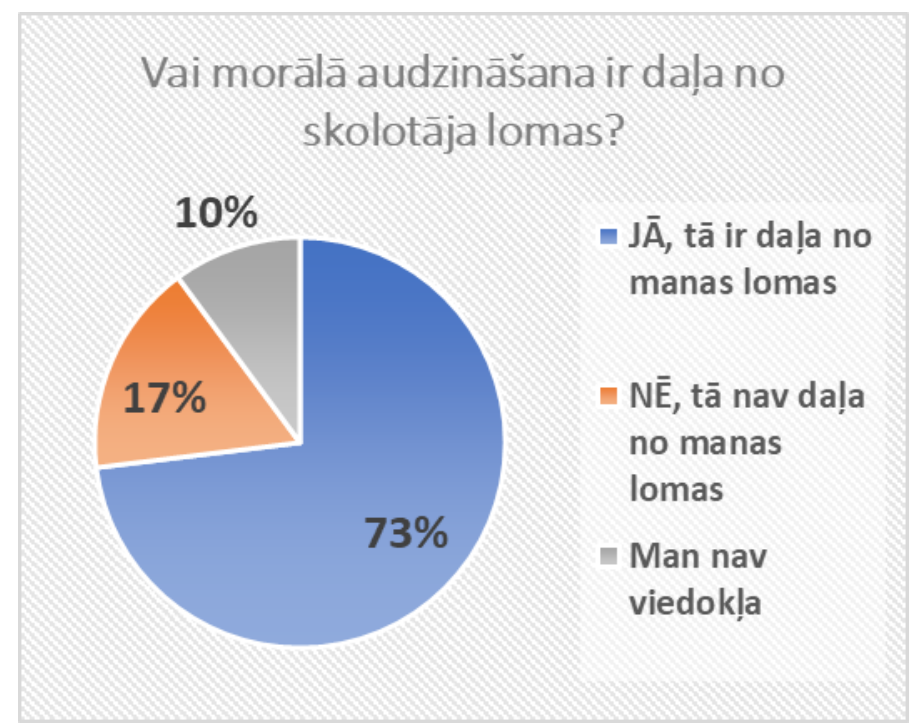

$73 \%$ no aptaujātajiem skolotājiem uzskatīja, ka skolēna morālā audzināšana un vērtību audzināšana ir daḷa no viṇu lomas, un tikai $17 \%$ nepiekrita tam. Bet loti izteiktas ir reǵionālās atškirīības šajā jautājumā $(\mathrm{p}<, 000)$. Latgalē $80 \%$ un Zemgalē $76 \%$ no skolotājiem jutās atbildīgi šajā jomā, bet Kurzemēe - tikai $50 \%$. Kāds skolotājs precizēja, "Jō, tā ir dala no manas lomas, bet ne mana atbildība." Kopumā skolotāji ievērojami biežāk uzskatīja, ka tā ir dala no viṇu lomas (73\% no skolotājiem), salīdzinot ar vecākiem (56\% - sk. ziṇojumu 2/5). 


\section{2\% no skolotājiem uzskatīja, ka var sekmēt skolēnu rakstura veidošanos mācību stundās}

Kuram no šiem diviem apgalvojumiem Jūs visvairāk piekrītat?

- VAR mācīt bērniem vērtības un palīdzēt viniem pilnveidot savu raksturu skolā mācību stundās, ar komandas darba uzdevumiem vai iesaistot bērnus brīvprātīgajā darbā

- NEVAR palīdzēt bērniem pilnveidot savu raksturu skolā, mācot šo tēmu mācību stundās; viñi vienkārši mācīsies to no citiem skolēniem un skolas pieredzes

\section{Vai iespējams sekmēt rakstura veidošanos mãcibu stundās?}

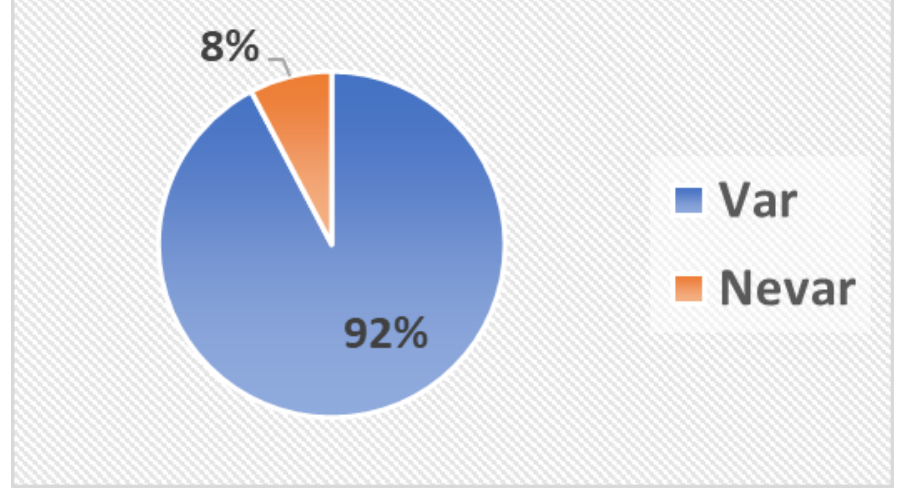

Gandrīz visi aptaujātie skolotāji $(92 \%, \mathrm{~N}=424)$ uzskatīja, ka ir iespējams sekmēt skolēnu morālo ieradumu veidošanos mācību stundās. Tikai $8 \%$ nepiekrita tam. Kā atzīmēja kāds skolotājs,

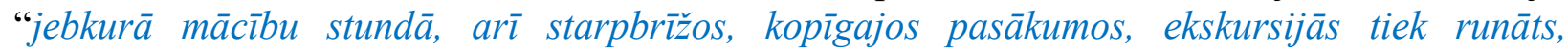
pārrunāts, radīta vide, lai skolēnos veidotos izpratne par vērtībām”. Cits kolēgis precizēja, ka "katra mācību stunda ir arì skolēna rakstura veidošanās, tāpēc uzsvars, sevišķi sākumskolā, jāvelta skolēnu audzināšanai", un piedāvāja konkrētu piemēru: "Kāpēc gan pirmdiena nevarētu sākties ar, piemēram, uzman̄̄bas audzināšanu, kas ir viena no tikumiskajām vērtībām. Ciemos atnāk uzmanība! Noskaidrojam, kāpēc uzmanība svarīga cilvēka dż̄̄ē, un turpinām mācību darbu. Stundas beigās rezumējot, kā veicās ar uzmanību." Cits skolotājs savu atbildi komentēja šādi: "Skola, protams, nevar izvairīties no audzināšanas, jo tā patiešām notiek gan mācību procesā, gan ārpus tā, gan mācī̌sanas laikāa, gan komunikācijā ar apkārtējiem cilvēkiem, bet loti tieši to mācìt un iemācìt nevar, tāpēc arī skola nevar par fokusu izvēlèties rakstura un tikumības audzināšanu, skolai jādod zināšanas un prasme mācīties, viss pārējais nāk klāt šajā procesā..." Šajā jautājumā skolotāju un vecāku viedokḷi pilnībā sakrita.

\section{7\% no skolotājiem uzskatīja, ka nav nepieciešams definēt attīstāmās} rakstura īpašības skolas dokumentos

Vai Jūs domājat, ka katras skolas dokumentos vajag skaidri definēt galvenās rakstura īpašības, ko tā vēlas attīstīt savos skolēnos?

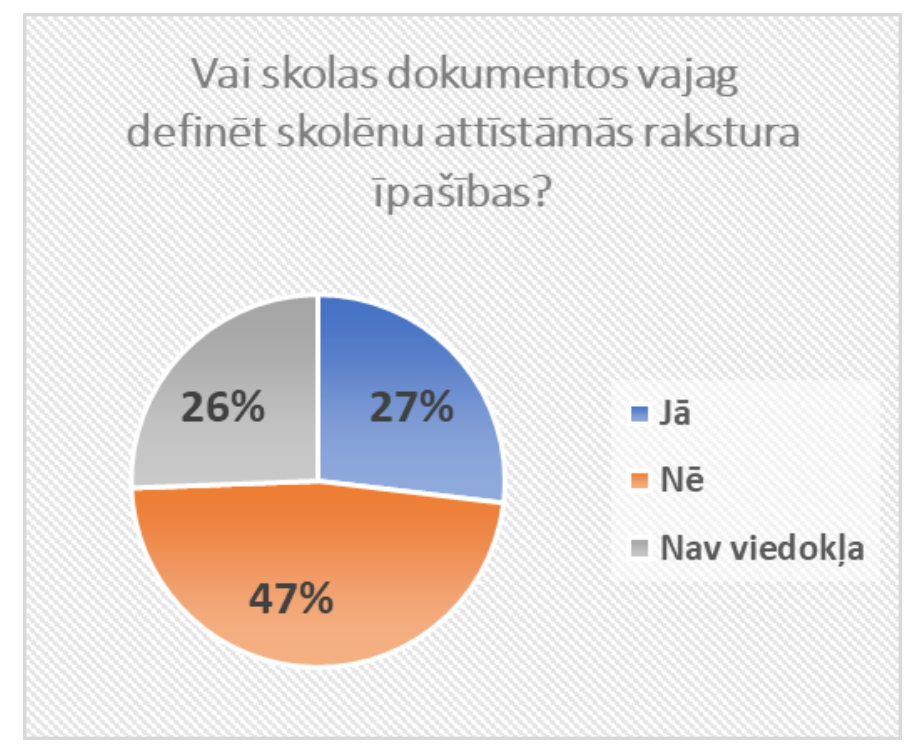

Kopumā, vairākums no skolotājiem $(47 \%$, $\mathrm{N}=221)$ uzskatīja, ka nav nepieciešams definēt attīstāmās rakstura īpašības skolas dokumentos, bet vajag kopīgi veltīt uzmanību šim jautājumam. Š̀i skolotāja izteiciens labi raksturo kopējo tendenci: "Skolas kolektīvam jāsāk skatīties uz laba rakstura veidošanos daudz nopietnāk." Tomēr regiionālās atškirības ir statistiski l’oti nozīmīgas $(p<, 000)$ : Rīgā un Zemgalē proporcija bija lielākā (respektīvi - 57\% un $55 \%$ ), bet Vidzemē vairākums skolotāju uzskatīja, ka to vajag darīt (36\% pret $30 \%$, kuri uzskatīja, ka nevajag). 


\section{0\% no skolotājiem uzskatīja, ka skolām jāsekmē skolēnu izpratne par} vērtībām un jāveicina skolēnu rakstura veidošanās

Kuram no šiem diviem apgalvojumiem Jūs visvairäk piekrītat?

- Skolām jāattīista skolēnu raksturs un jāveicina labas vērtības savos skolēnos

- Skolām jāfokusējas uz akadēmisko darbu, nevis jāveido skolēnu raksturs

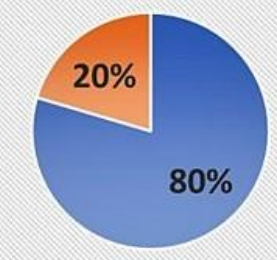

- Jārūpējas

n Nav jārūpējas

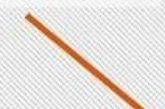

\section{Izvēlētie izskaidrojumi (N)}
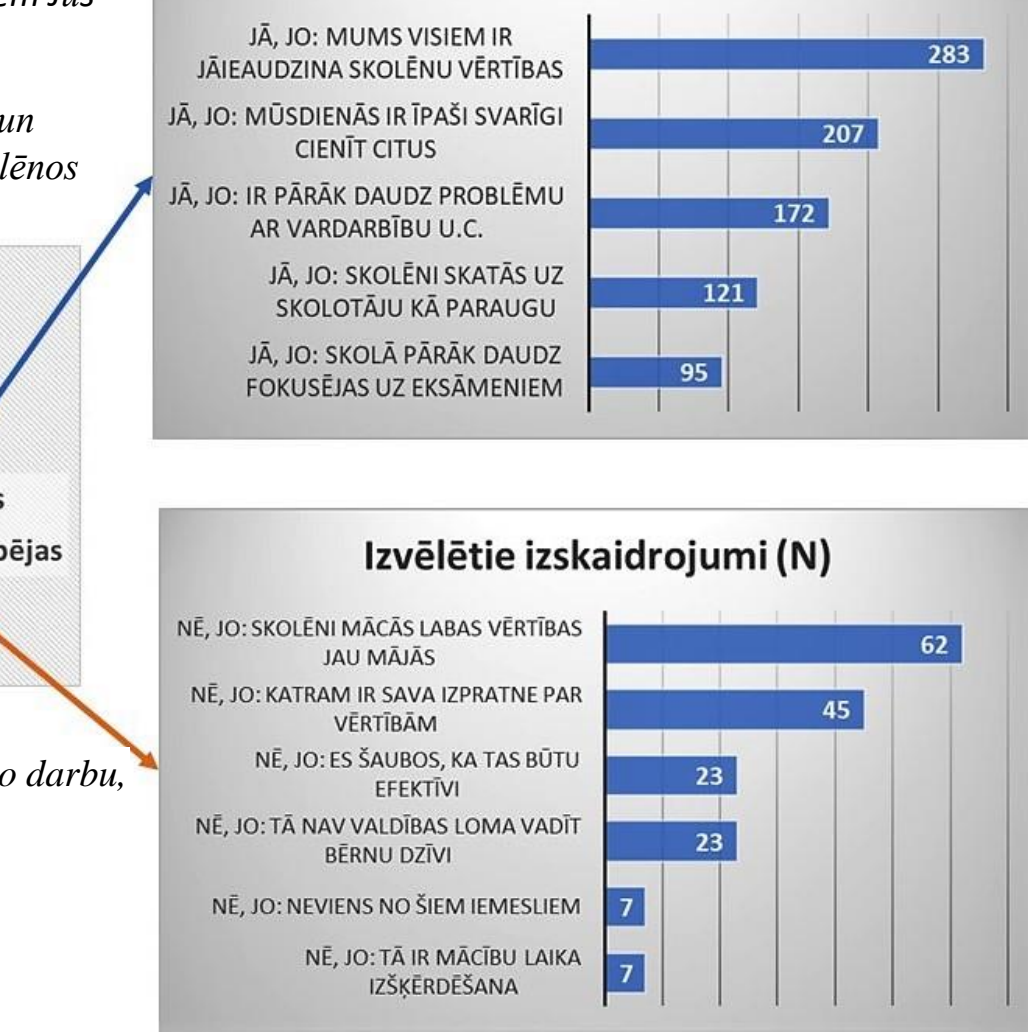

Kopumā 80\% no skolotājiem $(\mathrm{N}=370)$ drīzāk piekrita tam, ka skolām jāattīsta skolēnu raksturs un jāveicina labas vērtības savos skolēnos. Vidzemē proporcija bija vēl augstāka (91\%), bet Rīgā - viszemākā (74\%). Visbiežāk izvēlētie pamatojumi šim viedoklim bija "mums visiem ir jāieaudzina skolēnu vērtības" (32\% no izvēlēm, $\mathrm{N}=283)$ un "mūsdienās ir ìpaši svarīgi cienūt citus" (24\%). Skolotāju procents, kas izvēlējās šo variantu, bija ievērojami augstāks nekā vecāku procents (66\% - sk. ziņojumā 2/5). Tikai $20 \%$ no skolotājiem uzskatīja, ka skolām jāfokusējas uz akadēmisko darbu, un viņu visbiežāk izvēlētie pamatojumi bija - "skolēni mācās labas vērtības jau mājās" (37\%, N=62) un "katram ir sava izpratne par vērtībām" (27\%). Kā komentēja viens no skolotājiem, "Es uzskatu, ka skolotāji jau velta lielu dalı laika, lai nodarbotos ar skolènu audzināšanu ... un nepazīstu nevienu skolotāju, kurš bērniem mācītu pretējo vai bütu vienaldzīgs pret netikumisku, neētisku rīcību."

Skolotājiem, kuri uzskatīja, ka skolai mērḳtiecīgi jāsekmē skolēnu rakstura veidošanās, tika jautāts: “Vai Jūs uzskatāt, ka esat pietiekoši labi sagatavots, lai sekmētu skolēnu rakstura pilnveidošanos?" Kopumā 58\% ( $\mathrm{N}=217)$ uzskatīja, ka viṇi ir drīzāk, pietiekami vai piln̄̄gi sagatavoti šim darbam, bet proporcija bija lielāka Latgalē (38\%). Kopumā tikai 5\% (N=18) jutās vāji vai nepietiekami labi sagatavoti.

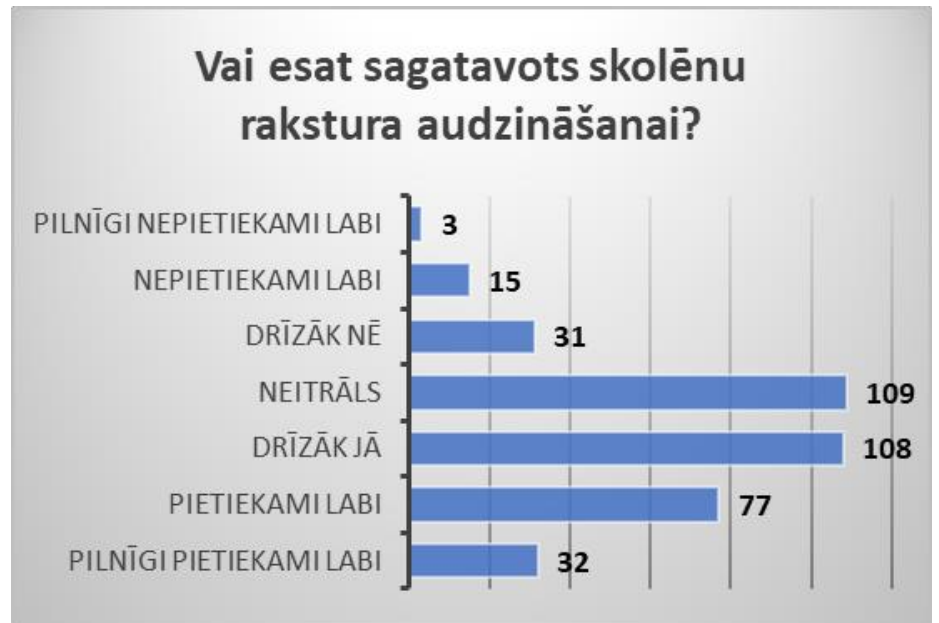




\section{Skolotāju ieteikumi skolēnu morālo ieradumu veidošanās sekmēšanai un skolotājiem nepieciešamais atbalsts}

Skolotāji brīvā formā izteicās par to, kā labāk sekmēt skolēnu tikumiskā rakstura veidošanos un kādu atbalstu viņi vēlētos saņemt šajā darbā. Kopumā viņu izteikumi satur vairāk nekā 3300 vārdus. Aizpildot anketu, skolotājiem netika piedāvāts saraksts, kur izvēlēties nepieciešamo atbalstu, bet katrs respondents izdomāja pats, kāds atbalsts viņam vajadzīgs vai nozīmīgs.

Vairāki respondenti uzsvēra šī pētījuma nozīmīgumu un nepieciešamību, ko ilustrē šis izteikums: "Tas ir tieši tas jautājums, par kuru pēdējos gados esmu domājusi, un patiess prieks, ka par šo problēmu ir aizdomājušies cilvēki, kuru rokās ir pašreizējās izglītības sistēmas pilnveidošana". Cits respondents uzrakstīja: "Gribēju piebilst, ka š̄ tēma ir ārkārtīgi nozìmīga skolas vidè, jo bèrni nāk no dažādām gimenèm, arī no nelabvēlīgām, tāpēc skola un skolotājs šiem bèrniem ir kā "bāka", pozit̄̄vais piemērs, ja vien audzinātājs un visa skolas komanda pievēršas šiem svarīgajiem jautājumiem." Vēl cits uzrakstīja: "Tēma izteikta aktuāla! Postmodernajā sabiedrībā vitāli nepieciešama!"

Runājot par NEPIECIEŠAMO ATBALSTU, visbiežāk skolotāji vēlētos saṇemt metodiskos materiālus, kas izmantojami darbam klasē (29\% no 244 piefiksētajiem izteikumiem). Starp tiem īpaši bieži pieminētas ir īsfilmiņas, kas ilustrē kādu no tikumiem, darba lapas izmantošanai mācību procesā, situācijas vai dilemmas diskusiju veicināšanai klasē un mācību plāni audzināšanas stundām. Otrais biežākais pieminētais vēlamais atbalsta veids bija kursu un semināru organizēšana par šo tēmu (21\%) ar speciālistu dalību un iespēju apmainīties ar pieredzi skolā vai ārpus tās. Skolotāji arī bieži pieminēja noderīgu metodisko ieteikumu nepieciešamību (10\%), t.sk. pedagoǵisko literatūru, tikumu definīcijas un pētījumus šajā jomā. Arī loti nozīmīga respondentiem škita sadarbība ar citiem kolēǵiem (8\% no izteikumiem) un atbalsts no skolas vadības: "Skolas kolektīvam jāsāk skatīties uz laba rakstura veidošanu daudz nopietnāk. Ir nepieciešami semināri, darba grupas, kas fokusējas tiě̌i uz rakstura veidošanu."

Viens no visbiežāk minētajiem SKOLOTĀJU IETEIKUMIEM bija sadarbība ar ğimenēm (9\% no izteikumiem): "Latvijas izglìtības sistēmas vidē ... mēs ikdienā regulāri šiem jautājumiem pievēršam lielu vērību. Bet liels ieguldījums un artava savos bērnos bütu jāiegulda vecākiem. Jo vinni ir ğimene, kas veido bērnā pamatvērtības". Sadarbība varētu veidoties arī kursos un semināros: "[vajag] kursus ne tikai skolotājiem, bet arī VECĀKIEM! Sadarbība! Bez sadarbības ar vecākiem nekas nesanāks". Kā ieteica kāda skolotāja, "Audzināšana sākas gimenē. Manuprāt, viens no lietderīgākajiem pasākumiem būtu nodarbības jaunajiem vecākiem, ǵimenèm, kuru laikā tiktu uzrunāti vecāki par tikumību, vērtībām utt." Cits respondents uzskatīja, ka, "piedāvājot kursus, seminārus gan vecākiem, gan pedagogiem par šādām tēmām, izdotos rast vienotu redzējumu par sasniedzamo rezultātu skolēnu tikumiskajā audzināšanā un rakstura izkopšanas attīstī̌sanā". L,oti vajadzīgs šim audzinošajam darbam ir arī sabiedrības atbalsts: "Bērnus [audzina] ar vecāku un pieaugušo piemēru. Mums ir vajadzīgs visas sabiedrības un īpaši vecāku atbalsts."

Šīs skolotājas izteikums lakoniski un precīzi apkopo daudzu respondentu domas: "Sākt ar sevi; vairāk vīriešu skolotāju lomā; sadarboties ar ǵimeni, debates, kopā būšana". Svarīgi n̦emt vērā arī citas skolotājas novērojums: "Manuprāt, l, loti nozīmīga tēma. Man ir radies iespaids, ka gimenēs, sabiedrībāa, politikā un arī skolā joprojām apzināti vai neapzināti tomēr vairāk tiek likts uzsvars uz tādu rakstura īpašîbu attīstīšanu kā mērķtiecība, rezultātu sasniegšana jebkādiem lìdzekḷiem, dažkārt aizmirstot par morāli. Poziț̄vais - situācija pēdējā laikā lēni, bet uzlabojas”. 


\section{Skolēnu morālā audzināšana Latvijas skolās}

\author{
Populārzinātnisks pētījuma ziṇojums (4/5) \\ TOPOŠO SKOLOTĀJU VIEDOKLIS
}

\author{
Dr. Manuel Joaquín Fernández González
}

Latvijas Universitātes Pedagoǵijas, psiholoğijas un mākslas fakultātes Pedagoǵijas zinātniskā institūta vadošais pētnieks Pēcdoktorantūras projekts "Izglīitības modernizācija Latvijas skolās, īstenojot inovatīvu pētniecībā balstītu programmu par 21. gadsimta kompetencēm un tikumu êtikas attīstību ar virtuālās telpas atbalstu (ARETE-school)" projekta Nr. 1.1.1.2/VIAA/1/16/071

Pētījuma konteksts. 2018. gadā tika veikts pētījums par skolēnu morālo ieradumu veidošanos skolās, kurā piedalījās vairāk nekā 2250 respondenti (skolēni, skolotāji, vecāki, topošie skolotāji, skolu un izglītības pārvaldes vadītāji) no visas Latvijas. Šajā ziņojumā prezentēts topošo skolotāju (studentu) viedoklis par pētîjuma jautājumiem, kas attiecas uz skolotāju lomu skolēnu morālajā audzināšanā un topošajiem skolotājiem nepieciešamo atbalstu šim darbam.

\section{Studentipa kursiem}

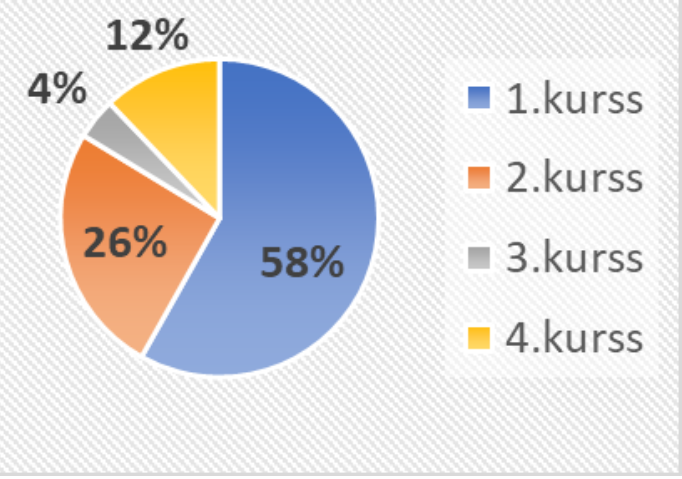

Par respondentiem. Pẹtījumā piedalījās 244 bakalaura studenti (topošie skolotāii). $90 \%$ bija sievietes. $60 \%$ no respondentiem bija mazāk nekā 23 gadi, bet vidējais vecums -24 gadi. Vairākums bija 1. un 2. kursa studenti (respektīvi $59 \%$ un $26 \%$ ), bet 3. un 4. kurss arī bija pārstāvēts. $64 \%$ no respondentiem studēja Rīgā, 17\% - Rēzeknē, 17\% Liepājā. Tika pārstāvēti gandrīz visi izglìitības posmi un mācību priekšmeti, bet visbiežāk - pirmskolas pedagogi (23\%), sākumskolas pedagogi (13\%), angḷu valodas skolotāji (12\%), mūzikas skolotāji $(11 \%)$, pamatskolas skolotāji (8\%), speciālās izglīīības skolotāji $(8 \%)$, sociālie pedagogi $(6 \%)$ un mājturības skolotāji $(6 \%)$.

86\% no topošajiem skolotājiem uzskatīja, ka skolēnu morālā audzināšana būs dalia no vinuu lomas

(Vai Jūs domājat, ka skolēna morālā audzināšana un vērtību audzināšana būs dala no Jūsu lomas?)

Vai skolēnu morālā audzināšana ir dala no skolotāja lomas?

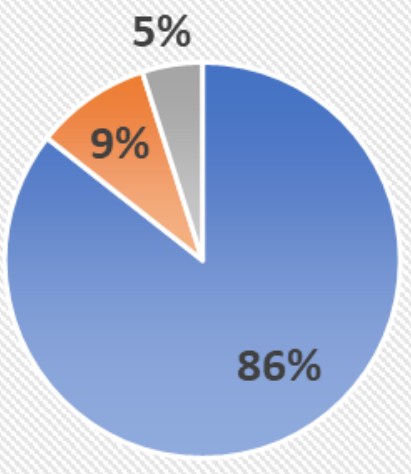

- JĀ, tā būs daḷa no manas lomas

- Nē, tā nebūs daḷa no manas lomas

- Nav viedokla
$86 \%$ no aptaujātajiem studentiem uzskatīja, ka skolēnu morālā audzināšana ir daḷa no vinu lomas, un tikai $9 \%$ nepiekrita tam. Salīdzinot ar citu sektoru viedokḷiem (sk. ziṇojumā 2/5 un 3/5), kopumā studenti ievērojami biežāk uzskatîja, ka tā ir dạ̣a no vinnu lomas $(86 \%$ no studentiem), salīdzinot ar skolotājiem (73\%) un vecākiem (56\%). Kāda respondenta precizēja: "Lai gan skolotājam ir dažādas iespējas, mācību materiāli utt., ar kuru palīdzìbu stundās runāt par vērtībām, daudz svarīgāku lomu šajā situācijā spèlè vecāki un vinnu rādìtais piemērs." 


\section{3\% no studentiem uzskatīja, ka var sekmēt skolēnu rakstura veidošanos} mācību stundās

Kuram no šiem diviem apgalvojumiem Jūs visvairāk piekrītat?

- VAR mācīt bērniem vērtības un palīdzēt viņiem pilnveidot savu raksturu skolā mācību stundās, ar komandas darba uzdevumiem vai iesaistot bērnus brīvprātīgajā darbā

- NEVAR palīdzēt bērniem pilnveidot savu raksturu skolā, mācot šo tēmu mācību stundās; vini vienkārši mācīsies to no citiem skolēniem un skolas pieredzes

\section{Vai iespējams sekmēt rakstura veidošanos mācibu stundās?}

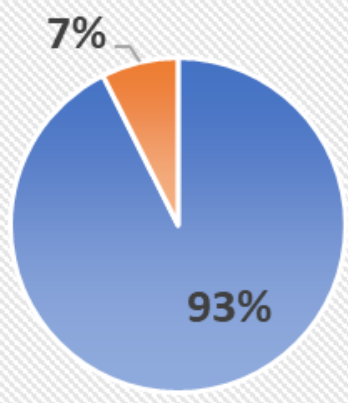

Var

Nevar

Gandrīz visi aptaujātie studenti $(92 \%, \mathrm{~N}=225)$ uzskatīja, ka ir iespējams sekmēt skolēnu morālo ieradumu veidošanos mācību stundās. Tikai 7\% nepiekrita tam. Šajā jautājumā studentu, skolotāju un vecāku viedokḷi pilnībā sakrita.

Savos komentāros respondenti niansēja savu viedokli: Kā atzīmēja kāds students, "Nevar fokusēties tikai uz bērna labo vērtību izpratnes attīstību vai tikai uz viņa zinātniskuma pilnveidošanu. Skolotājam nav jāveido skolēna raksturs, bet skolotājam ir jāparāda, kas ir īsts cilvēks un kā tādam klūt caur mācībām”. Cita studente uzskatīja, ka "Bērni mācās no mūsu piemēra. Neizbēgami, ka arī uz ielas un citur mēs visi kaut ko mācāmies viens no otra un citām dzīves situācijām. Bērniem arī tas pats! Nevar būt ētisks un tikumisks tikai akadēmiskajās stundās. Cilvēks ir tāds visu laiku vai nav vispār. Skolai ir liela nozīme. Vairāk var iemāè̄t arī ar pusstundu darbu (morāli, ètisku vērtību, tikumisko), bet tāpēc nav jānoraida akadēmiskās stundas. Ir jābūt gan tam, gan tam, lai kḷūtu par cilvēku... Skola gan var iemācìt morāli, ètiski, tikumīgi rīkoties / dzīvot."

\section{7\% no studentiem uzskatīja, ka nav nepieciešams definēt attīstāmās rakstura} ipašības skolas dokumentos

Vai Jūs domājat, ka katras skolas dokumentos vajag skaidri definēt galvenās rakstura īpašības, ko tā vēlas attīstīt savos skolēnos?

Vai skolas dokumentos vajag definēt skolēnu attīstāmās rakstura ipašības?

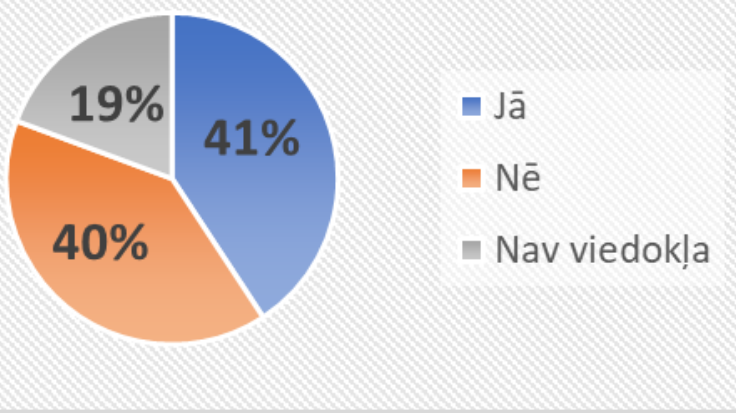

Studentu viedokḷu sadalījums par to, vai ir nepieciešams definēt attīstāmās rakstura īpašības skolas dokumentos vai - nē, bija ḷoti līdzīgs $(41 \%$ par, $40 \%$ pret $)$. Tomēr atšķirības starp kursiem bija statistiski loti nozīmīgas ( $p<, 005)$ : 1. un 2. kursā tikai 38\% no studentiem uzskatīija, ka to vajag darīt, bet 4. kursā proporcija bija izteikti lielāka: $62 \%$. Viens students uzskatija, ka "Skolènu rakstura īpašības ir individuāla lieta, un rakstura ìpaš̄ibas nav jāreglamentē skolas iekšējās kārtības līmenī. Tas izveidotu noteiktu "rakstura ideālu", kuram visiem būtu jāatbilst, un tas nav pareizi." 


\section{4\% no topošajiem skolotājiem uzskatīja, ka skolām jāsekmē skolēnu izpratne par vērtībām un jāveicina skolēnu rakstura veidošanās}

Kuram no šiem diviem apgalvojumiem Jūs visvairāk piekrītat?

- Skolām jāattīsta skolēnu raksturs un jāveicina labas vērtības savos skolēnos

Vai skolai jārūpējas par skolēnu rakstura veidošanos?

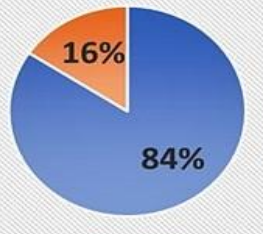

- Skolām jāfokusējas uz akadēmisko darbu, nevis jāmēgina veidot skolēnu raksturu

\section{Izvēlētie izskaidrojumi (N)}
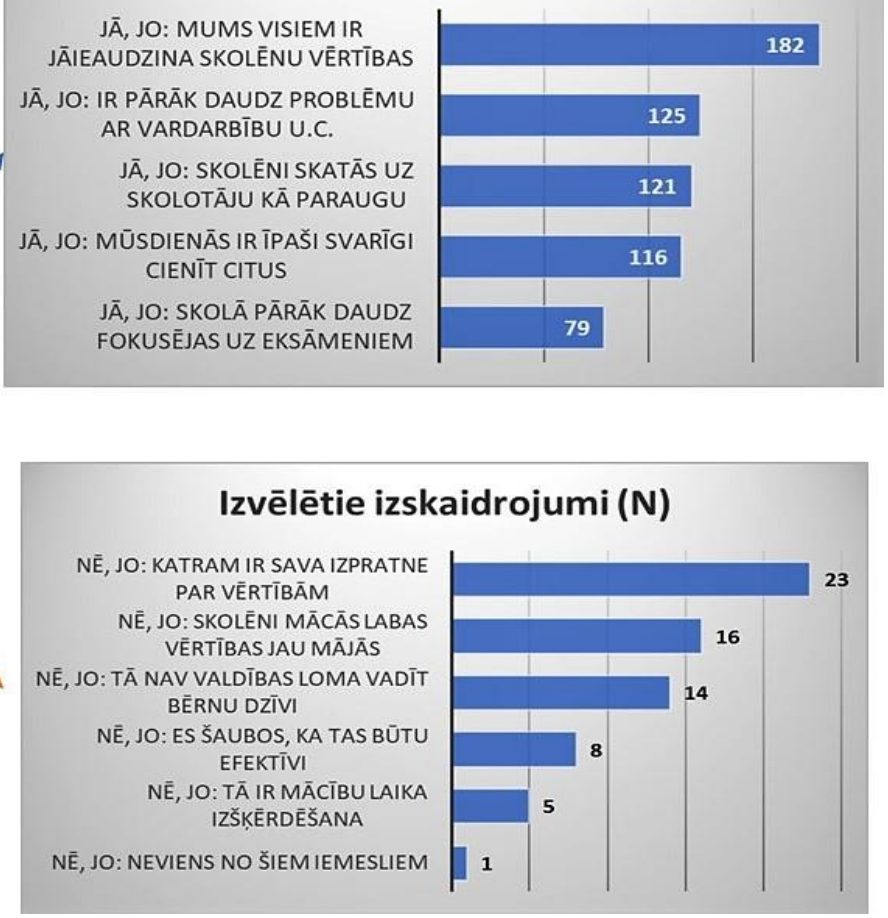

Kopumā 84\% no studentiem ( $\mathrm{N}=205)$ piekrita tam, ka skolām jāattīsta skolēnu raksturs un jāveicina labas vērtības savos skolēnos. Jo vecāks bija studentu kurss, jo augstāka proporcija: 1. kursā 80\%, 2. kursā 85\%, bet 3. un 4. kursā - 90\%. Viena studente komentēja: "Pirmskolās un skolās vajag vairāk pievērst uzmanību bērna tikumiskajai audzināšanai, stāstìt bērniem par attiecībām ar cilvēkiem, ieaudzināt mīlestību pret pasauli. Tas ir grūti, bet tomēr vajag vairāk par to runāt un rādìt ar savu piemēru."

Visbiežāk izvēlētie pamatojumi šim viedoklim bija - "mums visiem ir jāieaudzina skolēnu vērtības" (29\% no izvēlēm, N=182), "ir pārāk daudz problēmu ar vardarbību" (20\%), kā arī "skolēni skatās uz skolotāju kā paraugu" (19\%). Divas pēdējās izvēles bija mazāk izteiktas skolotāju un vecāku atbildēs. Tikai $16 \%$ no studentiem uzskatīja, ka skolām drīzāk jāfokusējas uz akadēmisko darbu, jo "katram ir sava izpratne par vêrtībām" (34\% - augstākā proporcija visos sektoros) un "skolēni mācās labas vērtības jau mājās" (24\%). Viens students uzskatīja, ka "skolotāji jau tā ir simts profesijas vienā, mēginot vienlaicīgi mācìt un audzināt nav efektīvi... par to jārūpējas vecākiem." Cita studente precizēja, ka "skolā ir jāfokusējas uz akadēmisko darbu, kur jau šobrīd ir pietiekami daudz vērtīborientētu tēmu", vēl cita - "skolai jāveido raksturs, nevis pilnīgi jāuznemas par to atbildība."

Studentiem, kuri uzskatīja, ka skolai jārūpējas par rakstura veidošanos, tika jautāts: "Vai augstskolā Jūs sagatavo, lai sekmētu skolēnu rakstura pilnveidošanos?" Kopumā 49\% (N=96) uzskatîja, ka augstskolā labi vai l̦oti labi sagatavo šim darbam, bet tika konstatētas statistiski nozīmīgas atškirīìbas atkarībā no kursa ( $p=, 023):$. kursā proporcija bija 70\%, 3. kursā $-56 \%$, bet 4 . kursā $-20 \%$. Viens respondents uzskatīja, ka “"Skola2030” ir atklātas atziņas par šo tēmu, taču nepieciešama detalizētāka informācija pedagogu izglītošana".

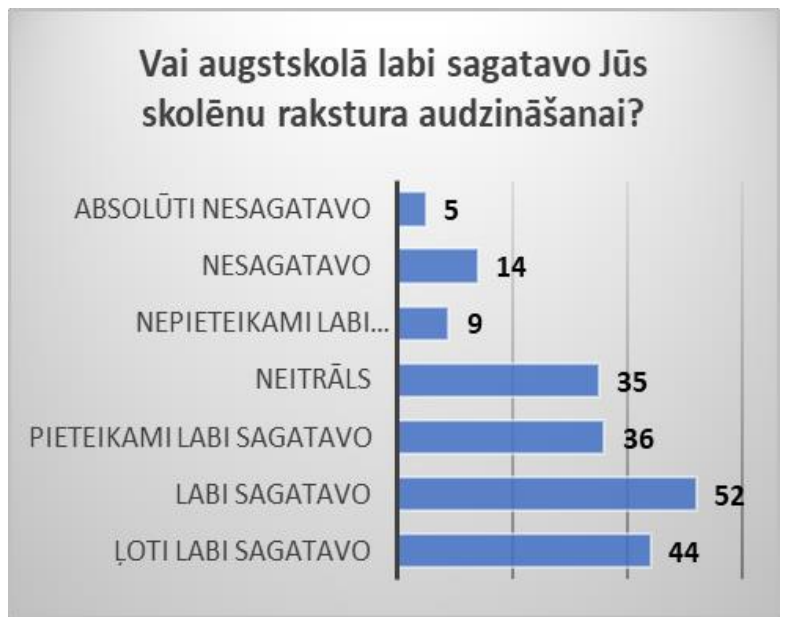




\section{Ieteikumi skolēnu morālo ieradumu veidošanās sekmēšanai skolā topošo} skolotāju izteikumos un skolotājiem nepieciešamais atbalsts

Studenti brīvā formā izteicās, atbildot uz jautājumu "Kādu atbalstu Jūs vēlètos saņemt, lai varētu sekmēt Jüsu skolēnu laba rakstura pilnveidošanos, kad sāksiet strādāt skolā?" Kopumā vinuu izteikumi satur vairāk nekā 3000 vārdus. Katrs respondents izdomāja pats, kāds atbalsts vinam būtu nozīmīgs, jo anketā netika piedāvāts saraksts, kur izvēlēties vēlamo atbalsta veidu.

Vairāki respondenti uzsvēra š̄ pētījuma nozīmīgumu un nepieciešamību: "Man ir prieks, ka par šo tiek runāts, jo tas ir l̦oti nozīmīgi, bet Latvijā netaisnīgi tiek attiecināts tikai uz seksuālo audzināšanu". Cits students rakstīja: "L̦oti viegli pārprotama tēma. Priecājos, ka tiek ar to saistīta izpēte." Daži studenti novēlēja, "lai šis pētījums sekmētos ar panākumiem un lai vairāk visiem ir skaidrs un saprotams, ka tikumiskā audzināšana nav nekas slikts".

Runājot par nepieciešamo atbalstu, studenti visbiežāk minēja sadarbību ar ǵimenēm (19\% no 151 piefiksētajiem izteikumiem). G̦imenes vislabāk pazīst savus bērnus, un vecāki ir pirmie atbildīgi par bērnu audzināšanu: "Viss sākas ğimenē! Cik daudz velta bērnam laiku, tāds arī ir bērns!". Runājot par šo sadarbību, kāda topošā skolotāja uzskatīja, ka "pamatā ir nepieciešams sadarboties ar skolēna vecākiem, saprast, kādas ir vērtības vinu gímenē, lai bērnam neradītu apjukumu, ka mājās vinu audzina vienā veidā, bet skolā pavisam citādāk". Tajā sadarbībā var rasties grūtības atšķirīgu uzskatu dēl, ko ilustrē šis izteikums: "Brīžam jūties bezspēcìgi tajā visā, ja gimenēs bērni sastopas ar vērtībām, kas neatbilst tikumiskai audzināšanai. Tad paliek lügšana Dievam un piemērs, ko varu parādīt no savas puses". Vairāki studenti vēlētos saņemt no gimenēm vairāk informācijas par bērniem un just ǵimeṇu atbalstu šajā darbā: "Sagaidu, lai vecāki man arī lauj runāt ar bērnu, apvaicātos un interesēties par viņu, nevis sagaida no manis tikai "sausu" mācību procesu".

Topošie skolotāji uzskatīja, ka labu atbalstu skolēnu bērnu morālajai audzināšanai viṇi varētu saṇemt kursos (13\%), ar metodiskajiem ieteikumiem un grāmatām (10\%), bet tiem būtu jābūt praktiskiem, balstītiem uz reālām situācijām (36\% no šiem izteikumiem): "[vēlètos] konferences un seminārus, kur neveidojas tikai ,, sausais atbirums”, bet gan tiek gūti reālas dzìves piemēri un paraugi." Šo tendenci labi ilustrē šīs studentes ieteikums: "Augstskolā varētu būt garāks kurss, kas saistās ar šo tematu, ar piemēriem un varbūt arī situāciju izspēèem".

Respondenti bieži minēja arī nepieciešamību pēc atbalsta no speciālistiem (10\%) un pieredzes bagātiem skolotājiem (9\%): "Vēlētos vairāk dzirdèt pieredzējušo skolotāju viedokļus un stāstus, lai zinātu, kā rīkoties". Bet tomēr daudziem respondentiem praktiskā pieredze bija īpaši svarīga: "Vislabāk mūs sagatavo dzīve un realitāte. Protams, mēs varam mācìties teoriju un metodes, kā pareizāk būtu strādāt ar bērniem, kam ir jāpievērš uzmanūba utt. Bet realitāte ir mazliet citādāka... Manuprāt, tas ir loti labi, ka mums kāa skolotājiem ir tik daudz prakses. Tas lauj mums sastapties ar problēmām... [un] to visu redzēt savām acīm. Prakse ir tas, kas ir nepieciešams."

Vairāki studenti apzīmēja nepieciešamību pašiem attīstīt savu personī̄bu, jo "daudz atkarīgs no skolotāja kā personības un no tā, vai vinam būs šāda vēlme pilnveidot rakstura īpaš̄ibas skolēniem". Kā komentēja kāda studente, "es vèlètos pati attīstìties kā pilnvêrtīga un stipra persona, lai nākotnē palīdzètu arī skolēniem attīstīties kā person̄̄bām - stiprām, pārliecinātām un dzìvespriecīgām". Skolas vadībai būtu jāatbalsta skolotāji, lai jaunajiem skolotājiem veidotos "drošības sajūta un emocionāls komforts" "skolotāja ideju realizēšanai un atbalstī̌sanai."

Atbildēs tika minēta arī morālās audzināšanas pozitīvā ietekme mācību procesā: "Lai skolotājiem izdodas skolēnos ieaudzināt tikumu un raksturu, kas skolēniem liks saprast, ka mācīšanās ir vērtība!" Kā cita studente atzīmēja: "es gribu uzzināt... kā korekti audzināt [skolènu] raksturu, lai vini paši izvēlas strādāt un veicināt savu rakstura pilnveidošanu".

Vairāk informācijas par pētūjumu: manuels.fernandezs@lu.lv $\quad$ Rīgā

2019. gada martā 


\section{Skolēnu morālā audzināšana Latvijas skolās}

\author{
Populārzinātnisks pētījuma ziṇojums (5/5)
}

\section{SKOLU UN IZGLĪTĪBAS PĀRVALDES VADĪTĀJU VIEDOKLIS}

\author{
Dr. Manuel Joaquín Fernández González
}

\begin{abstract}
Latvijas Universitātes Pedagoǵijas, psiholoǵijas un mākslas fakultātes Pedagoǵijas zinātniskā institūta vadošais pētnieks Pēcdoktorantūras projekts "Izglîtības modernizācija Latvijas skolās, īstenojot inovatîvu pētniecībā balstītu programmu par 21. gadsimta kompetencēm un tikumu ētikas attīstību ar virtuālās telpas atbalstu (ARETE-school)" projekta Nr. 1.1.1.2/VIAA/1/16/071
\end{abstract}

Pētījuma konteksts. 2018. gadā tika veikts pētījums par skolēnu morālo ieradumu veidošanos skolās, kurā piedalījās vairāk nekā 2250 respondenti (skolēni, skolotāji, vecāki, topošie skolotāji, skolu un izglītības pārvaldes vadītāji) no visas Latvijas. Šajā ziṇojumā prezentēts skolu un izglītības pārvaldes vadītāju (turpmāk - vadītāju) viedoklis par pētījuma jautājumiem, kas attiecas uz skolas lomu skolēnu morālajā audzināšanā un jauno skolotāju sagatavošanu.

\section{Respondenti pa regioniem}

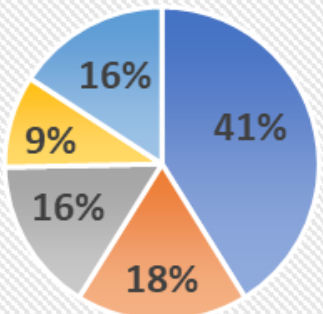

- Rīga

- Latgale

Kurzeme

Vidzeme

Zemgale

\section{Par respondentiem}

Pētījumā piedalījās 159 vadītāji (127 no skolām un 32 no izglìtības pārvaldēm). 90\% bija sievietes. Jaunākajam respondentam bija 26 gadi, bet vidējais vecums bija 50 gadi. Lielākā daḷa no respondentiem bija no Rīgas (41\%), bet pētījumā tika pārstāvēti visi Latvijas reǵioni. Respondentu vidējais darba stāžs bija 13 gadi, bet $29 \%$ no viṇiem stāžs bija līdz 5 gadiem. Tika pārstāvētas gan lauku, gan pilsētu skolas, lielās un mazās.

75\% no vadītājiem uzskatīja, ka skolēnu morālā audzināšana ir daḷa no viṇu lomas (Vai Jūs domājat, ka skolēna morālā audzināšana ir daḷa no Jūsu lomas?)

Vai morālā audzināšanair da!̣ a no skolotāja lomas?

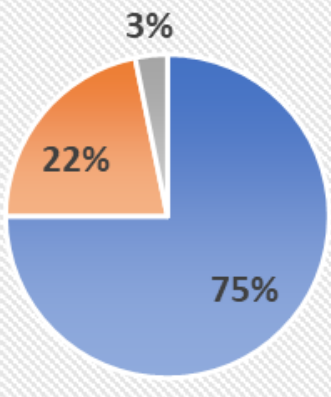
atbildība

- NĒ, tā nav skolotāju atbildība
Reǵionālās atšḳirības (\%)

- JĀ, tā ir skolotāju

- Man nav viedokla

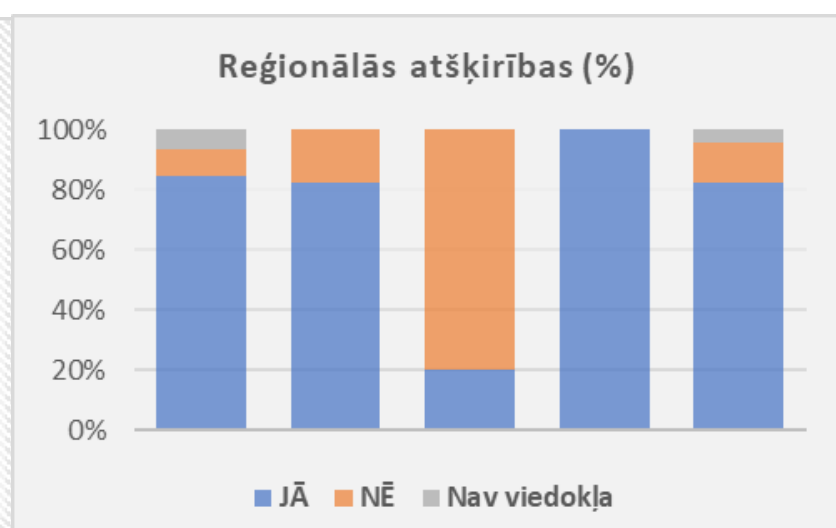

Kopumā $75 \%$ no aptaujātajiem vadīiājiem uzskatīija, ka skolēna morālā audzināšana ir daḷa no skolotāju lomas. Bet reǵionālās atšķirīîas bija ḷoti izteiktas $(\mathrm{p}<, 000)$. Visaugstākais piekritēju procents bija Vidzemē (100\%), pārējos reǵionos - virs $80 \%$, bet tikai $20 \%$ no Kurzemes respondentiem piekrita tam (Kurzemes skolotājiem arī bija viszemākā piekrišana tam - 50\%, sk. ziṇojumā 3/5). Kopuma vadītāju un skolotāju viedokli procentuāli sakrita (respektīvi - 75\% un $73 \%$ ), bet vecāku un topošo skolotāju piekritēju procenti atšksiras (respektīvi - 56\% un $86 \%$ ). 


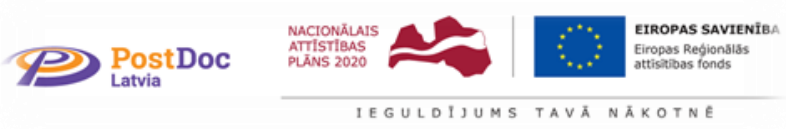

\section{9\% no vadītājiem uzskatīja, ka var sekmēt skolēnu rakstura veidošanos mācību stundās}

Kuram no šiem diviem apgalvojumiem Jūs visvairāk piekrītat?

- VAR mācīt bērniem vērtības un palīdzēt vingiem pilnveidot savu raksturu skolā mācību stundās, ar komandas darba uzdevumiem vai iesaistot bērnus brīvprātīgajā darbā

- NEVAR palīdzèt bērniem pilnveidot savu raksturu skolā, mācot šo tēmu mācību stundās; viņi vienkārši mācīsies to no citiem skolēniem un skolas pieredzes

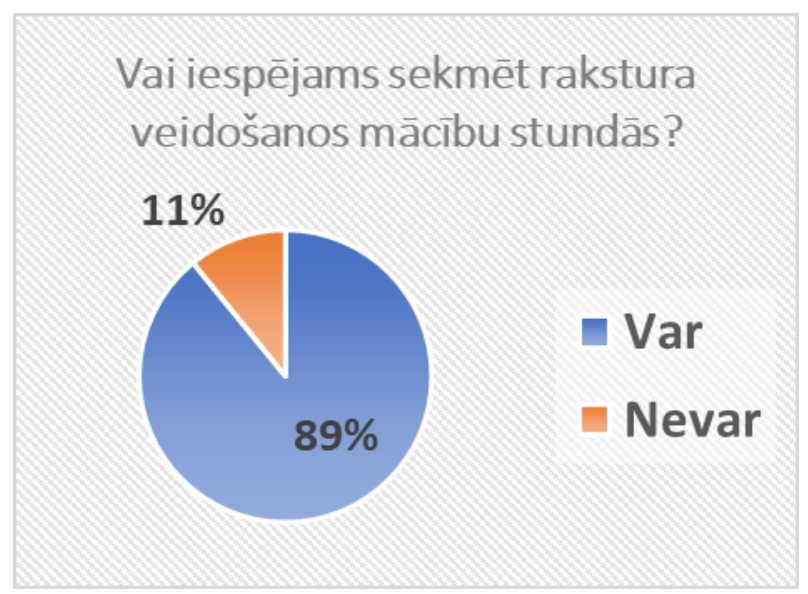

Gandrīz visi aptaujātie vadītāji $(89 \%, \mathrm{~N}=139)$ uzskatīja, ka ir iespējams sekmēt skolēnu morālo ieradumu veidošanos mācību stundās. Tikai $11 \%$ nepiekrita tam. Kā atzīmēja kāds vadītājs, svarīgi uzsvērt "mācību un audzināšanas darba vienotība skolas ikdienas procesā". Š̄̄s skolas direktores izvērstais komentārs labi atspoguḷo daudzu respondentu domas: "Turpināt izglītot skolēnus par mērķiem, gribasspēku un attīstīt visas, tai skaitā karjeras vadības prasmes, kas šos jautājumus iekl̦auj un palìdz jauniešiem veikt sabiedriskos pienākumus skolā un organizēt skolēnu aktivitātēs izglìtojamo lìdzpārvaldēe un skolas padomēe veikt brīvprātīgo darbu, vadīt stundas sākumskolas skolēniem par morāles tēmām un situācijām, lai arī skolotāju kolekt̄̄vs savā uzvedībā un darbībā bütu ka vienota komanda, kas ìsteno skolas vīziju un visi justos lepni par piederību savai ǵimenei, skolai, valstij”. Šajā jautājumā visu sektoru viedokḷi sakrita.

\section{7\% no vadītājiem uzskatīja, ka nav nepieciešams definēt attīstāmās rakstura īpašības skolas dokumentos}

Vai Jūs domājat, ka katras skolas dokumentos vajag skaidri definēt galvenās rakstura īpaš̄ibas, ko tā vèlas attīstīt savos skolēnos?

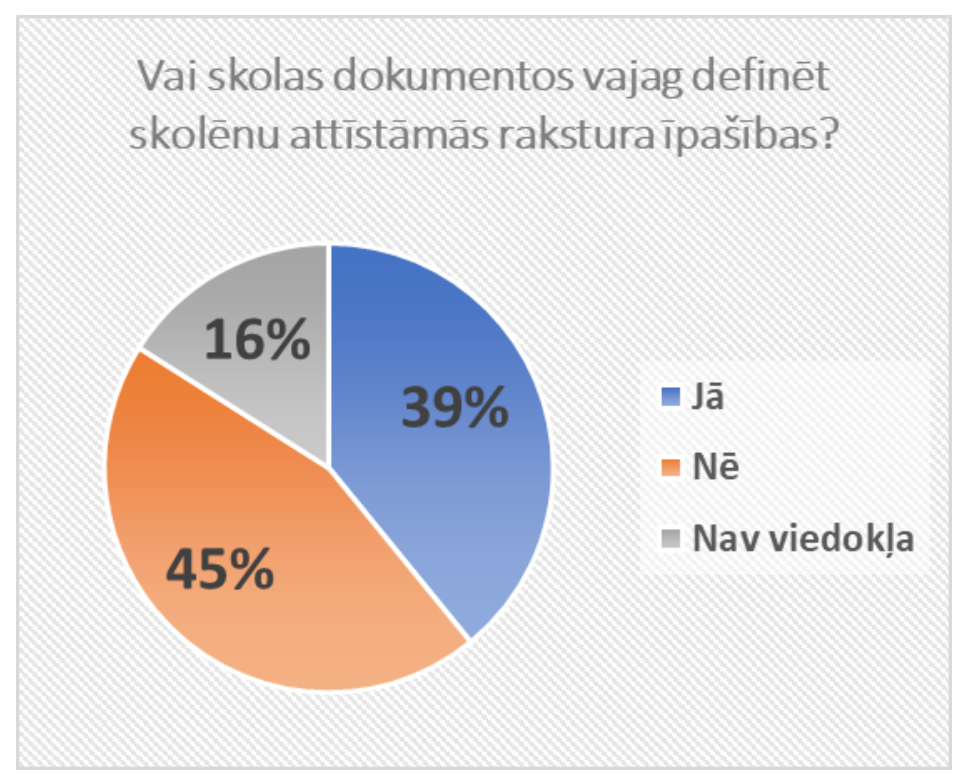

Kopumā vairākums no vadītājiem (45\%, N=70) uzskatīja, ka nav nepieciešams definēt attīstāmās rakstura īpašíbas skolas dokumentos. Tomēr Vidzemē $60 \%$ no vadītājiem uzskatīja, ka to vajag darīt (Vidzemes skolotāji arī bija vienīgie, kas deva priekšroku skolēnu rakstura īpašību akcentēšanai skolas dokumentos). Daži vadītāji pauda viedokli, ka tas varētu palīdzēt "strādāt saskaņoti, apzināti un komandā", kā arī "vienoties par kopīgām vērtībām ar vienotu izpratni". 


\section{6\% no vadītājiem uzskatīja, ka skolām jāsekmē skolēnu izpratne par vērtībām un jāveicina skolēnu rakstura veidošanās}

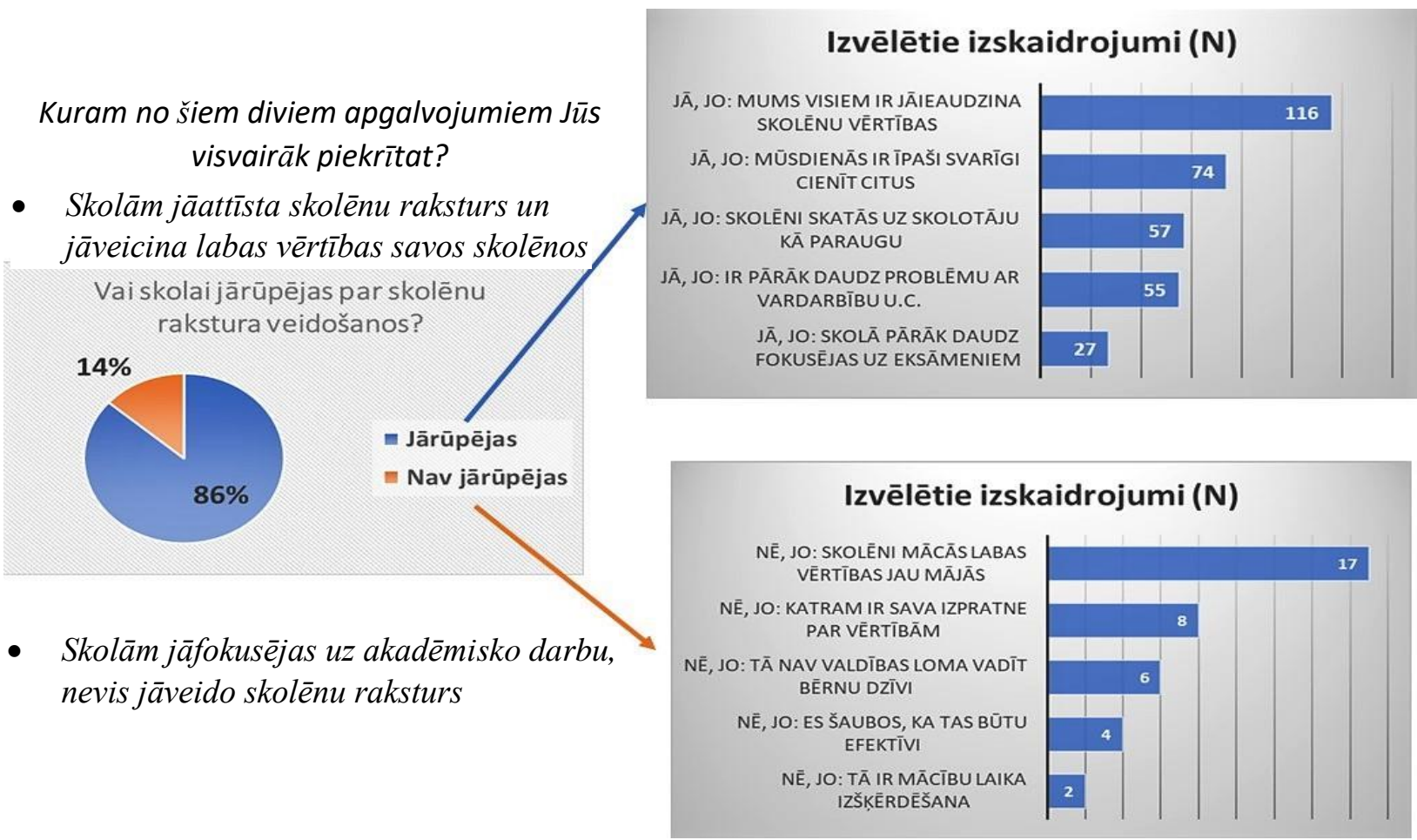

Kopumā $86 \%$ no apjautātajiem vadītājiem $(\mathrm{N}=134)$ piekrita tam, ka skolām jāattīsta skolēnu raksturs un jāveicina labas vērtības savos skolēnos. Kurzemē un Vidzemē proporcija bija vēl augstāka (respektīvi - 96\% un 93\%), bet Latgalē - viszemākā (79\%). Visbiežāk izvēlētie pamatojumi šim viedoklim bija - "mums visiem ir jāieaudzina skolēnu vērtības" (35\% no izvēlēm, N=116) un "mūsdienās ir ìpaši svarīgi cienīt citus" (22\%). Tikai 20\% no vadītājiem uzskatīja, ka skolām jāfokusējas uz akadēmisko darbu, un viṇu visbiežāk izvēlētais pamatojums bija - "skolēni mācās labas vērtības jau mājās" (46\% no tiem, N=17). Viens no direktoriem komentēja, ka "akadèmiskā izglìtība nav vērtība, ja skolēniem nav tikumu izpratnes un stipra rakstura." Kāds izglītības pārvaldes darbinieks uzsvēra, ka "mums ir brīnišḳiga folklora latviešu tikumu kodekss, sāksim ar to! Liela loma skolotājam, jo skolotājs ar savu piemēru, darbību katrā stundā var atklāt un audzināt tikumiskās vērtības".

Vadītājiem, kuri uzskatīja, ka skolai jāsekmē skolēnu rakstura veidošanās, tika jautāts: "Vai skolotāji ir pietiekoši labi sagatavoti, lai sekmētu skolēnu rakstura pilnveidošanos?" Kopumā 42\% no vadītājiem $(\mathrm{N}=57)$ uzskatīja, ka skolotāji drīzāk nav vai pilnīgi nepietiekami labi sagatavoti šim darbam. Proporcija bija vēl lielāka Zemgalē (50\%) un Rīgā (49\%). Š̀̃ proporcija ḷoti izteikti atšḳiras no skolotāju (13\%) un studentu (14\%) proporcijas, kuri tā domāja. Šis direktores komentārs ilustrē šo tendenci: "Topošie skolotāji netiek pienācīgi sagatavoti darbam skolā. Esmu bijusi mentors vairākiem praktikantiem". Citi respondenti bija niansētāki: "Nevar apgalvot par visiem jaunajiem skolotājiem kopumā - ir gan labi sagatavoti, gan vāji jaunie skolotāji."

\section{Vai skolotāji ir sagatavoti, lai sekmētu skolēnu rakstura pilnveidošanos?}

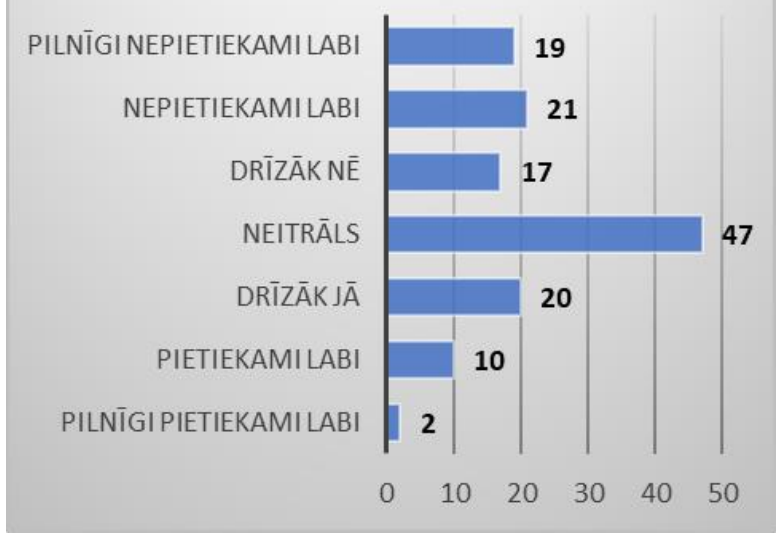




\section{Vadītāju ieteikumi skolēnu morālo ieradumu veidošanās sekmēšanai un skolotājiem nepieciešamais atbalsts vadītāju izteikumos}

Vadītāji brīvā formā izteicās par to, kā labāk sekmēt skolēnu tikumiskā rakstura veidošanos skolās un sagatavot jaunos skolotājus šim darbam. Kopumā vinu izteikumi satur vairāk nekā 2500 vārdus. Aizpildot anketu, katrs respondents izdomāja pats savus paša ieteikumus šajās jomās.

Vairāki respondenti uzvēra šì pètījuma nozīmīgumu: piemēram, skolas direktore rakstīja: “Man prieks, ka tiek risināti tik aktuāli jautājumi plašākē mērogāa. Paldies VIAA, RD IKSD darbiniekiem ... un visām skolām, kas tika iesaistītas”. Kāda izglīî̀bas pārvaldes darbiniece arī komentēja: "Tēma ir loti nozìmīga un aktualizējama".

Runājot par SKOLĒNU MORĀLĀS AUDZINĀŠANAS SEKMĒŠANU SKOLĀ, biežāk tika uzvērta nepieciešamība sadarboties ar ġimenēm (15\% no 84 izteikumiem) un nodarboties praktiski (ārpusskolas nodarbības, darbs skolas kolektīvā, humanitārie un brīvprātīgie darbi), nevis tikai teorētiskās nodarbībās $(15 \%)$, ko ilustrē š̄ direktora komentārs: "Vairāk darboties praktiski, veicināt skolēnu, skolotāju, vecāku sadarbību, organizējot daudzveidīgus pasākumus, akcijas, brīvprātīgo darbu”. Svarīgi arī, lai skolas kolektīvam būtu vienota izpratne un kopīgi izstrādāts plāns skolēnu rakstura audzināšanai, kā arī runāt ar skolēniem: "Skolotājiem savā rīcībā [var] demonstrēt paraugus un apspriest ar skolēniem vinu rīcības cēloṇus un sekas". Tas veicinātu cieņas, atbildības un pienākumu apziņas veidošanos skolēnos. Daži respondenti minēja arī sabiedrības un skolas kultūras svarīgumu šajā jomā: "Radìt apstākl̦us, kuros skolēns apzinās, ka viņš ir nozīmīga dalı no skolas, no sabiedrības, no kolektīva. Izskaidrot, ka arī skolēns var paveikt daudz, lai sabiedrība mainītos pozit̄̄vā virzienā. Jāaizmirst jēdziens - "man pienākas". Jāattīsta domāšana - "kā es varu palīdzēt?"”. Izglīîibas pārvaldes darbinieki uzsvēra vajadzību atbalstīt skolas vadītājus un skolotājus, piedāvājot papildu izglītības iespējas šajā jomā, jo "katram pedagogam jāsāk ar savas person̄̄bas pilnveidi un tad rādīt piemēru, iedvesmot, iedrošināt skolēnus". "Karjeras attīstības plānu varētu iekḷaut vairāk pasākumu par tēmu” arī ar mērķi attīstīt "prasmi komunicēties ar vecākiem, taču nepien,emt to viedokli kā vienīgo patieso".

Ieteikumos par TOPOŠO SKOLOTĀJU SAGATAVOŠANU bija divas galvenās tēmas: Prakses un pieredzes nepieciešamība (40\% no izteikumiem) un skolotāju personības nozīmība (31\%). Vairāki direktori uzskatīja, ka "jaunajiem skolotājiem katastrofāli trūkst prakses", jo augstskolā "loti daudz tiek koncentrēta uzman̄̄ba uz akadēmiskām zināšanām, pazaudējot praktiskumu". "L,oti liela nozìme ir tam, kāds raksturs ir skolotājam”, jo "katram skolotājam ir sava darba pieeja un $k \bar{a} \breve{s}$, is skolotājs pilnveidos skolēna raksturu, ir arī atkarīgs no skolotāja rakstura īpašì̄bām". Tāpēc svarīga pašu skolotāju personības pilnveide: "jaunajam pedagogam jāaudzina vispirms savs raksturs, sevi jāizzina un jāpilnveido". No vienas puses, jaunie skolotāji " $k \bar{a}$ personības ir atvērtāki, labāk spēj izprast skolēnu intereses, vajadzības, $k \bar{a}$ arī sekmēt raksturu pilnveidošanu” un viņi "nesatur ar gadiem akumulēto rukšksēšanu”, bet vairāki respondenti arī minēja jauno skolotāju piemērus, kuri "neveicina ne tikumisko audzināšanu, ne rakstura audzināšanu", jo "pietrūkst motivācijas, vēlmes būt skolotājam! Zinu, ka varu pal̦auties uz vecākās paaudzes pedagogiem - viņi tur doto vārdu, paveic savu darbu ar humoru un aizrautību". Jāṇem vērā arī, ka "skolotāju jau neizglìto tikai augstskola - vērtības, tikumisko fonu, atbild̄̄bu, cien,u, godprātīgu attieksmi pret darbu jau iemācās (vai neiemācās) gimenē, pirmsskolas iestādē". Tādēḷ jauno skolotāju atlase ir svarīgs moments, kā ilustrē šīs direktores komentārs: "Pieangušo grūti mainìt. Manuprāt, jāsāk ar atbilstošu kadru piesaisti pedagogijai... Tādējādi labais tiktu pavairots daudz efektīvāk".

Nobeigumā šì direktora vēlējums labi atspoguḷo respondentu attieksmi, piedaloties pētījumā: "Paldies! Lai mums kopā izdodas veidot savos bērnos labas rakstura un tikumiskās īpašības!"

Vairāk informācijas par pētijumu: manuels.fernandezs@lu.lv Rīgā

2019. gada martā 